\title{
ECAR-2705 Physics Analysis to Support Advanced Test Reactor Critical Facility Testing of the KJRR-FAI Experiment
}

Joseph W Nielsen

March 2020

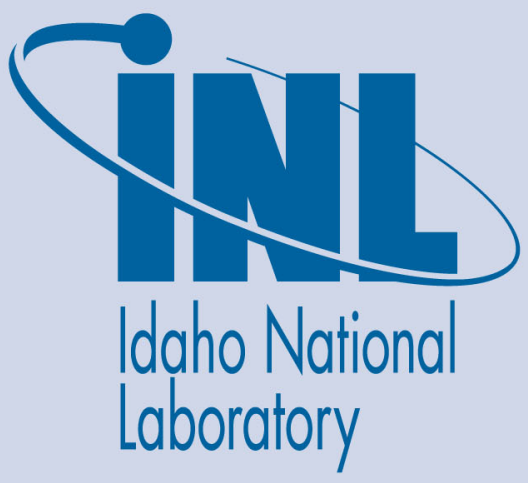

The INL is a U.S. Department of Energy National Laboratory operated by Battelle Energy Alliance 


\title{
ECAR-2705 Physics Analysis to Support Advanced Test Reactor Critical Facility Testing of the KJRR-FAl Experiment
}

\author{
Joseph W Nielsen
}

March 2020

Idaho National Laboratory Idaho Falls, Idaho 83415

http://www.inl.gov

Prepared for the U.S. Department of Energy Office of Nuclear Energy Under DOE Idaho Operations Office Contract DE-AC07-05ID14517 
TEM-10200-

1

$03 / 01 / 2012$

ENGINEERING CALCULATIONS AND ANALYSIS REPORT

Rev. 06

Physics Analysis to Support Advanced Test Reactor Critical Facility Testing of the Title: KJRR-FAl Experiment

ECAR

No.:

2705

ECAR Rev.

Project File

No.: $\quad \underline{0}$ No.:

$\mathrm{N} / \mathrm{A}$

Date: $01 / 29 / 2015$

\begin{tabular}{|l|c|}
\hline 1. Quality Level (QL) No. & 1 \\
\hline 2. QL Determination No. & ATR Comp-000245 \\
\hline 3. Engineering Job (EJ) No. & $X$ \\
\hline 4. SSC ID & $X$ \\
\hline 5. Building & $X$ \\
\hline 6. Site Area & $X$ \\
\hline
\end{tabular}

Professional Engineer's Stamp

See LWP-10010 for requirements.

7. Objective/Purpose:

The Ki-Jang Research Reactor (KJRR) currently under construction is in the process of qualifying fuel elements. It has been proposed to test the KJRR Fuel Assembly Irradiation (KJRR-FAI) experiment in the Advanced Test Reactor (ATR) in the Northeast Flux Trap (NEFT) [1]. Prior to irradiation in the ATR, physics measurements will be made in the ATR Critical Facility (ATRC). This ECAR documents the analysis performed to support physics testing of the KJRR-FAl experiment in ATRC and demonstrate compliance with the SAR-192 [2]. The following calculations are performed to demonstrate compliance:

- Reactivity worth of the KJRR-FAI experiment, KJRR-FAl water filled holder, water filled NEFT, and large irradiation housing assembly (LIHA) with Low Specific Activity Cobalt (LSA) and Al fillers

- Estimated critical shim positions

- Power distribution of the ATRC driver fuel and KJRR-FAl experiment

- Density and temperature coefficients of reactivity of the moderator

- Safety rod worth calculations assuming the most reactive worth rod is stuck

- Outer Shim Control Cylinder worth measurements for ATRC with the KJRR-FAI experiment 
TEM-10200-

1

$03 / 01 / 2012$

ENGINEERING CALCULATIONS AND ANALYSIS REPORT

Rev. 06

Physics Analysis to Support Advanced Test Reactor Critical Facility Testing of the Title: KJRR-FAl Experiment

ECAR ECAR Rev. Project File

No.: $2705 \quad$ No.: $\quad \underline{0}$ No.: N/A Date: $\underline{01 / 29 / 2015}$

8. If revision, please state the reason and list sections and/or pages being affected:

9. Conclusions/Recommendations:

This ECAR documents the physics analysis for the KJRR-FAI experiment in the ATRC. The ECAR has determined a core loading of experiments and driver fuel that meet the requirements in SAR-192 [2]. The proposed core loading for experiments is presented in Table 1. The driver fuel consists of using 31 standard ATRC fuel elements with a Mark VII (7F) fuel element in Position 5 and 8 Mark VII NB elements in Positions 22 through 29.

The reactivity worth of the KJRR-FAl experiment relative to a water filled flux trap, given the specified core loading, is $2.76 \$$. The large irradiation housing assembly with 9 LSA Cobalt capsules and $14 \mathrm{Al}$ fillers has a reactivity worth of $-0.18 \$$. The temperature reactivity coefficient will be negative due to a negative void coefficient. The minimum safety rod worth for the proposed configuration with KJRR-FAI is $6.27 \$$ assuming the east safety rod (highest worth) is stuck. This complies with the minimum shutdown worth of the safety rods of $5.3 \$$.

The calculated heating rates were determined using MCNP to evaluate the power distribution in the ATRC driver fuel as well as the KJRR-FAI experiment. SAR-192 [2] assumes a maximum power density to average power density ratio of 4-to- 1 in the ATRC core. The peak power density to average power density in the ATRC with KJRR-FAI is 3.33 .

The OSCC worth curves were developed from MCNP models. The total OSCC worth is slightly more with the KJRR-FAl experiment inserted. The worth curve does not change to an extent sufficient to affect the accident analysis for a reactivity insertion accident documented in SAR-192 [2]. The presence and increased power from KJRR-FAI experiment increases the worth of the NE OSCC bank. The worth curves will be measured in ATRC and used to validate computational models for insertion in ATR. Based on the calculated worth curves, the expected balanced critical shim position for the proposed loading at 35.2 degrees in ATRC. 
TEM-10200-

1

$03 / 01 / 2012$

ENGINEERING CALCULATIONS AND ANALYSIS REPORT

Rev. 06

Physics Analysis to Support Advanced Test Reactor Critical Facility Testing of the

Title: KJRR-FAl Experiment

ECAR

No.:

2705

ECAR Rev.

Project File

No.: $\quad 0 \quad$ No.:

$\mathrm{N} / \mathrm{A}$

Date: $01 / 29 / 2015$

\section{CONTENTS}

PROJECT ROLES AND RESPONSIBILITIES ..........................................................................4

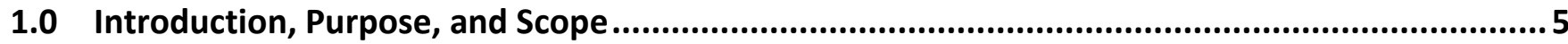

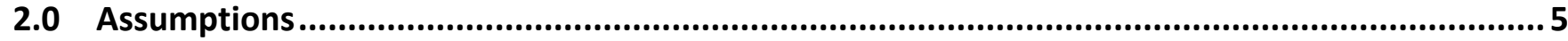

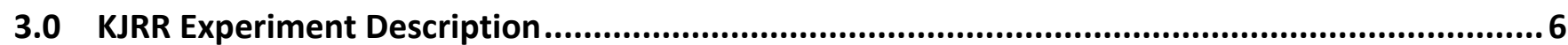

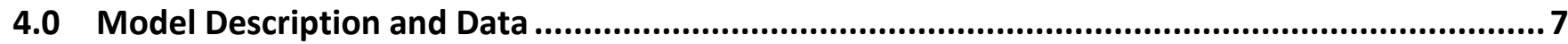

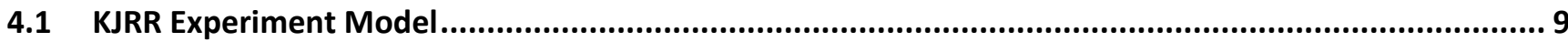

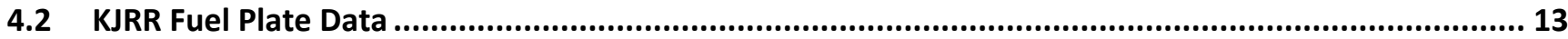

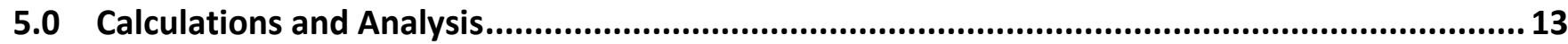

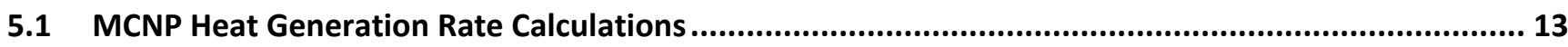

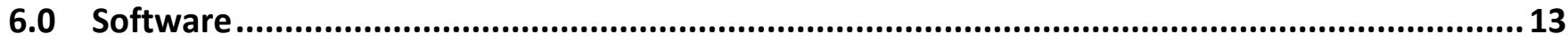

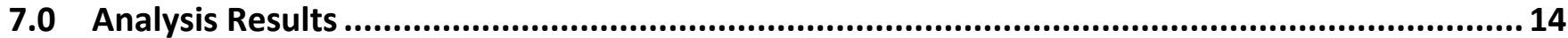

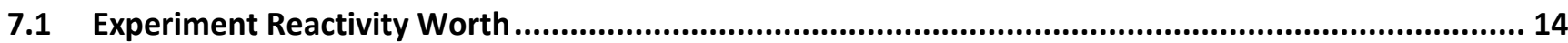

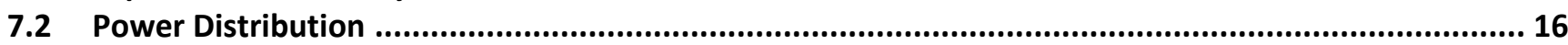

7.3 Moderator Density and Temperature Coefficient of Reactivity.................................................... 18

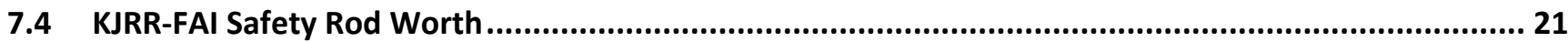

7.5 KJRR-FAI OSCC Worth Curves and Neck Shim Worths ..................................................................... 22

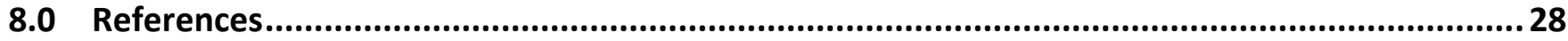

Attachment A - Calculated KJRR-FAI experiment heating ........................................................ 30

Attachment B - Calculated reactivity changes for core reconfiguration ......................................... 41 
TEM-10200-

1

$03 / 01 / 2012$

ENGINEERING CALCULATIONS AND ANALYSIS REPORT

Rev. 06

Physics Analysis to Support Advanced Test Reactor Critical Facility Testing of the Title: KJRR-FAl Experiment

ECAR

No:

2705

ECAR Rev.

Project File

No.: $\quad 0 \quad$ No.:

$\mathrm{N} / \mathrm{A}$

Date: $01 / 29 / 2015$

\section{PROJECT ROLES AND RESPONSIBILITIES}

\begin{tabular}{|c|c|c|c|}
\hline Project Role & Name (Typed) & Organization & Pages covered (if applicable) \\
\hline Performer & J. W. Nielsen & C660 & \\
\hline Checker $^{a}$ & E. T. Swain & C660 & \\
\hline Independent Reviewer & M. R. Holtz & W418 & \\
\hline CUI Reviewer ${ }^{c}$ & E. T. Swain & C660 & \\
\hline Manager $^{d}$ & D. J. Schoonen & C660 & \\
\hline Requestor ${ }^{\mathrm{e}}$ & A. A. Beasley & C630 & \\
\hline Nuclear Safety & G. L. Sharp & $\mathrm{H} 710$ & \\
\hline Document Owner ${ }^{\mathrm{e}}$ & A. A. Beasley & $\mathrm{C} 630$ & \\
\hline
\end{tabular}

Responsibilities:

a. Confirmation of completeness, mathematical accuracy, and correctness of data and appropriateness of assumptions.

b. Concurrence of method or approach. See definition, LWP-10106.

c. Concurrence with the document's markings in accordance with LWP-11202.

d. Concurrence of procedure compliance. Concurrence with method/approach and conclusion.

e. Concurrence with the document's assumptions and input information. See definition of Acceptance, LWP-10200.

NOTE: $\quad$ Delete or mark "N/A" for project roles not engaged. Include ALL personnel and their roles listed above in the eCR system. The list of the roles above is not all inclusive. If needed, the list can be extended or reduced. 
ECAR-2705

Rev. 0

\subsection{Introduction, Purpose, and Scope}

The Ki-Jang Research Reactor (KJRR) currently under construction is in the process of qualifying fuel elements. It has been proposed to test the KJRR Fuel Assembly Irradiation (KJRR-FAI) experiment in the Advanced Test Reactor (ATR) in the Northeast Flux Trap (NEFT) [1]. Prior to irradiation in the ATR, physics measurements will be made in the ATR Critical Facility (ATRC). This ECAR documents the analysis performed to support irradiation of the KJRR-FAl experiment in ATRC and demonstrate compliance with SAR-192 [2]. The following calculations are performed to demonstrate compliance:

- Reactivity worth of the KJRR-FAl experiment, KJRR-FAl water filled holder, water filled NEFT, and large irradiation housing assembly (LIHA) with Low Specific Activity Cobalt (LSA) and Al fillers

- Estimated critical shim positions

- Power distribution of the ATRC driver fuel and KJRR-FAl experiment

- Density and temperature coefficients of reactivity of the moderator

- Safety rod worth calculations assuming the most reactive worth rod is stuck

- Outer Shim Control Cylinder worth for ATRC with the KJRR-FAl experiment

\subsection{Assumptions}

The assumptions used in this analysis are stated below:

1. The KJRR-FAl element is modeled in MCNP with nominal U-235 fuel loading and nominal conditions. The nominal U-235 loading is $618.30 \mathrm{~g}$ with an enrichment of $19.75 \% \mathrm{U}-235$ for a total U loading of $3130.6 \mathrm{~g}$.

2. The delayed neutron fraction assumed in reactivity worth measurements is 0.0072 [3].

3. The safety rods are assumed to be $36 \mathrm{in}$. long and when inserted the top of the safety rod is $3 \mathrm{in}$. below the top of the active fuel region of the core. 
ECAR-2705

Rev. 0

\subsection{KJRR Experiment Description}

The Korea Atomic Energy Research Institute (KAERI) has initiated the Ki-Jang Research Reactor (KJRR) project to construct a new dedicated radioisotope production facility in the Ki-Jang province of South Korea. The KJRR will employ a plate-type driver fuel assembly. The fuel meat will consist of uranium $7 \mathrm{wt} \%$ molybdenum (U-7Mo) metallic alloy particles dispersed in a blended matrix of pure aluminum and $5 \mathrm{wt} \%$ silicon [1]. The silicon was neglected in the models and will have a negligible effect on neutronic interactions. The uranium enrichment will be 19.75 wt\% U-235 and considered Low Enriched Uranium (LEU). Aluminum alloy 6061(Al-6061) will be used as the fuel plate cladding material (see Figure 1).

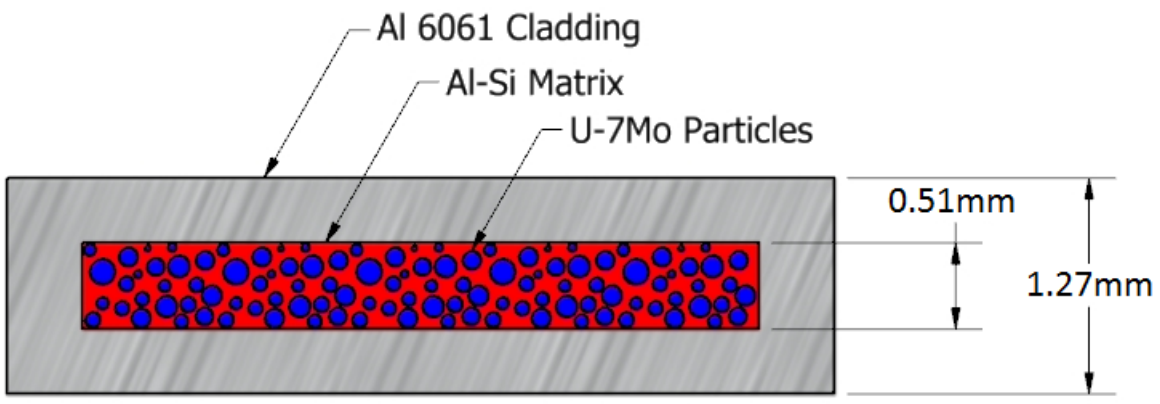

Figure 1: Fuel Plate Cross Section

Two fuel meat uranium densities of 8.0 and $6.5 \mathrm{~g}-\mathrm{U} / \mathrm{cm}^{3}$ will be used for the 19 interior plates and the 2 exterior plates of the KJRR fuel assembly, respectively. Fuel plate fabrication will be accomplished by hot roll bonding processes. Each of the 21 flat fuel plates will be assembled into a fuel assembly by swaging in the grooves of Al-6061 side plates giving $\sim 618 \mathrm{~g} \mathrm{U}-235$ for each KJRR fuel assembly (see Figure 2). The KJRR will receive fabricated driver fuel assemblies from a fabrication facility at the KAERI. A complete description of the KJRR-FAI experiment is described in Reference [1].

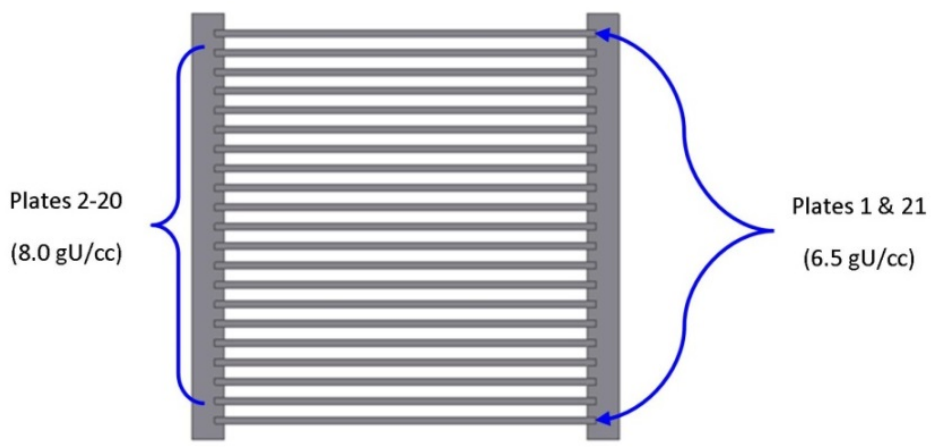

Figure 2: KJRR Fuel Assembly Top View 


\subsection{Model Description and Data}

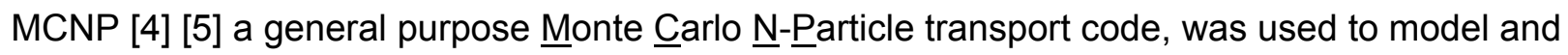
evaluate the KJRR-FAI experiment in the ATRC. Experiments used to validate the ATRC model are discussed in Reference [6]. Both the MCNP standard cross-section data libraries and the JENDL-3.2 cross-section library [7] were used to calculate the KJRR reactivity worths and fission heating.

A diagram of the ATRC model is shown in Figure 3. Parametric studies were performed to determine a core loading that met the safety rod worth limits of the ATRC with the KJRR-FAl experiment, as will be discussed in Section 7.3. The loading of the KJRR-FAl experiment creates a power tilt towards the NEFT resulting in a decreased safety rod worth of the safety rods in the S, SW, and W flux traps. Using the parametric loadings, the experiment and ATRC driver fuel loadings were determined to demonstrate compliance with the requirements in SAR-192 [2]. Table 1 documents the ATRC core loading for the KJRR-FAl experiment. Note that the detectors in the medium I positions and the cover over the empty Center In-pile Tube (CIPT) flow tube were not explicitly modeled in MCNP. 
ECAR-2705

Rev. 0
Physics Analysis to Support Advanced Test Reactor Critical

Facility Testing of the KJRR-FAI Experiment

Table 1. Loading of the ATRC core for the KJRR-FAI Experiment.

\begin{tabular}{|c|c|}
\hline Facility & Loading \\
\hline \multicolumn{2}{|l|}{ Flux Traps } \\
\hline NW & NR Dual Holder with $100 \% \mathrm{Hf}$ shrouds and Zr holders \\
\hline $\mathrm{E}$ & $\begin{array}{l}\text { Safety rod, Chopped Dummy IPT (CDIPT), and Small Irradiation Housing Assembly (SIHA) } \\
\text { with aluminum baskets containing three LSA cobalt capsules in Positions E-1, E-2, E-3, } \\
\text { E-4, E-5, E-6, and E-7. }\end{array}$ \\
\hline S & $\begin{array}{l}\text { Safety rod, Chopped Dummy IPT (CDIPT), and the SPICE Irradiation Facility with the MICE } \\
\text { Al secondary filler }\end{array}$ \\
\hline NE & KJRR-FAI test assembly \\
\hline $\mathrm{N}$ & Safety rod, Standard Inpile Tube (SIPT), water-filled flow tube \\
\hline W & Safety rod, Standard Inpile Tube (SIPT), flow tube, and 1.5-inch diameter aluminum filler \\
\hline SW & Safety rod, Standard Inpile Tube (SIPT), flow tube, and 1.5-inch diameter aluminum filler \\
\hline $\mathrm{C}$ & Center IPT consisting of pressure tube and water-filled flow tube with CIPT cover \\
\hline SE & Dummy Flux Trap Filler, Standard Inpile Tube (SIPT), water-filled flow tube \\
\hline \multicolumn{2}{|l|}{ A Irradiation Facilities } \\
\hline A-1 through $A-8$ & Aluminum baskets containing three LSA cobalt capsules \\
\hline A-9 through A-12 & Aluminum baskets containing three LSA cobalt capsules \\
\hline \multicolumn{2}{|l|}{ B Irradiation Facilities } \\
\hline B-1 through B-8 & Y-basket containing aluminum basket containing three LSA cobalt capsules \\
\hline \multicolumn{2}{|l|}{ H Irradiation Facilities } \\
\hline $\begin{array}{l}\mathrm{H}-5, \mathrm{H}-6, \mathrm{H}-8, \mathrm{H}-13, \mathrm{H}-15 \text {, } \\
\text { and } \mathrm{H}-16\end{array}$ & Aluminum baskets containing three LSA cobalt capsules \\
\hline $\begin{array}{l}\mathrm{H}-1, \mathrm{H}-4, \mathrm{H}-7, \mathrm{H}-9, \mathrm{H}-12 \text {, } \\
\text { and } \mathrm{H}-14\end{array}$ & Hf fixed shims \\
\hline $\mathrm{H}-3$ and $\mathrm{H}-11$ & N-16 flow tube mockup \\
\hline $\mathrm{H}-2$ and $\mathrm{H}-10$ & Flux wire monitor holders \\
\hline \multicolumn{2}{|l|}{ I Irradiation Facilities } \\
\hline I-1 through I-20 & $\begin{array}{l}\text { Aluminum filler except for Positions I-3 and I-9 which contain log count rate detector } \\
\text { thimbles }\end{array}$ \\
\hline \multicolumn{2}{|l|}{ Fuel Elements } \\
\hline Position 5 & One (1) Mark VII (7F) Fuel Element \\
\hline Positions 22 through 29 & Eight (8) Mark VII Non-Borated (7F NB) Fuel Elements \\
\hline $\begin{array}{l}\text { Positions 1-4, 6-21, and } \\
30-40\end{array}$ & Thirty one (31) ATRC standard fuel elements \\
\hline Neck Shims & All inserted \\
\hline
\end{tabular}




\subsection{KJRR Experiment Model}

The KJRR-FAl experiment was modeled based on the dimensions provided by Reference [8] and the associated basket hardware was modeled based on the dimensions provided by the drawings listed in Table 2. An MCNP diagram of the model is shown in Figure 3, Figure 4, and Figure 5. What can be seen in Figure 5 is the addition of water in the axial direction due to the reduction of the outer holder assembly. The outer holder assembly is an aluminum cylindrical pipe with a square hole. The outer radius of the cylinder is machined down to an outer square configuration to increase water moderation in the region $+/-25 \mathrm{~cm}$ from core center (see Figure 5), leaving approximately $5 \mathrm{~cm}$ of active fuel meat on the ends in the cylindrical portion of the holder. This design feature reduces water moderator on the ends and reduces the axial end peaking due to edge effects.

Table 2. KJRR-FAI Experiment Configuration Details.

\begin{tabular}{|ll|}
\hline $\begin{array}{l}\text { INL } \\
\text { Drawing }\end{array}$ & Drawing Title \\
\hline 604472 & KJRR Experiment Outer Basket Assembly and Details \\
\hline 604471 & KJRR Experiment Inner Fuel Basket Assembly and Details \\
\hline 604473 & KJRR Experiment Basket Assembly and Installation Orientation \\
\hline
\end{tabular}




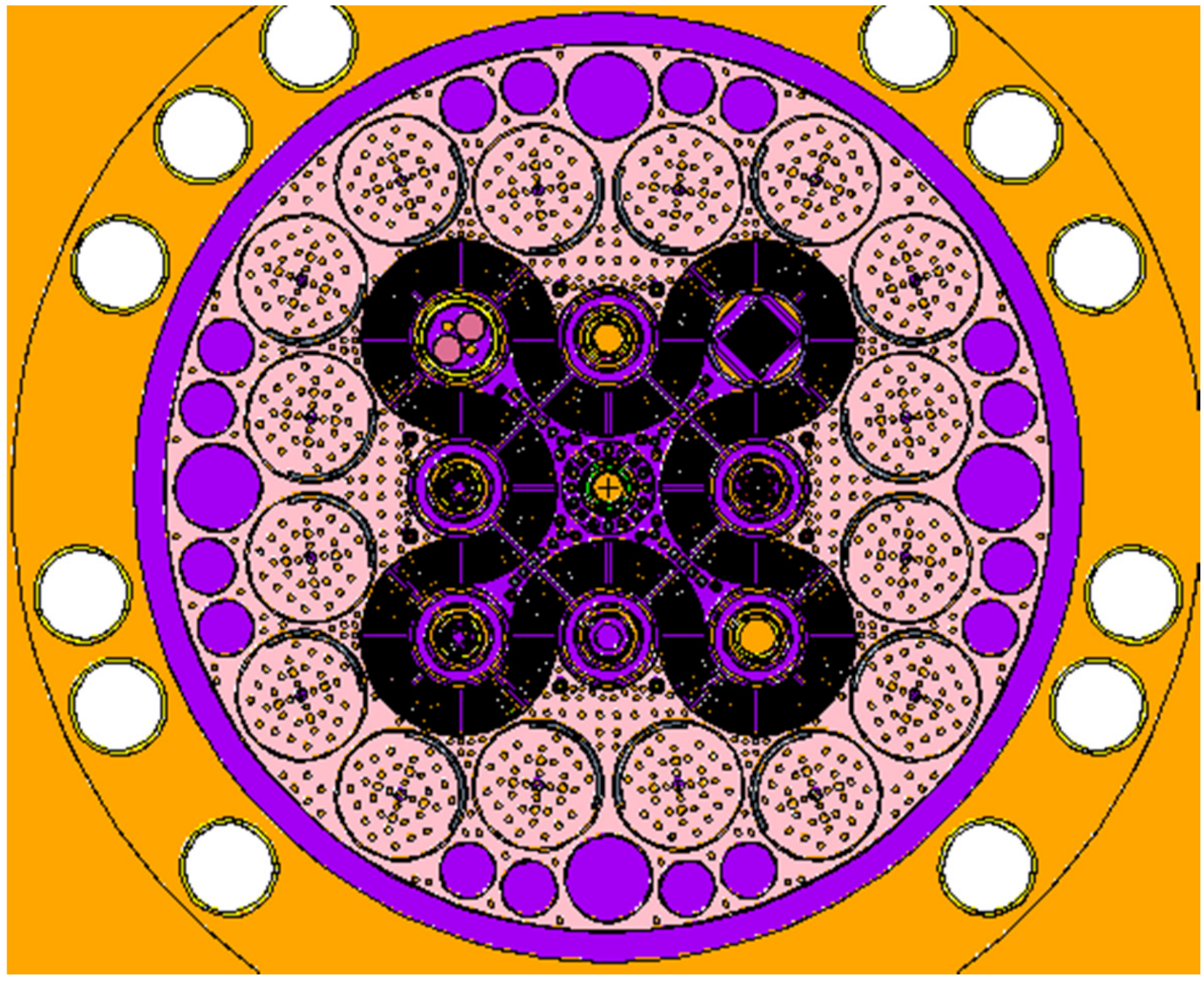

Figure 3. MCNP model of the ATRC core with KJRR-FAI. 
ECAR-2705

Rev. 0
Physics Analysis to Support Advanced Test Reactor Critical Facility Testing of the KJRR-FAI Experiment

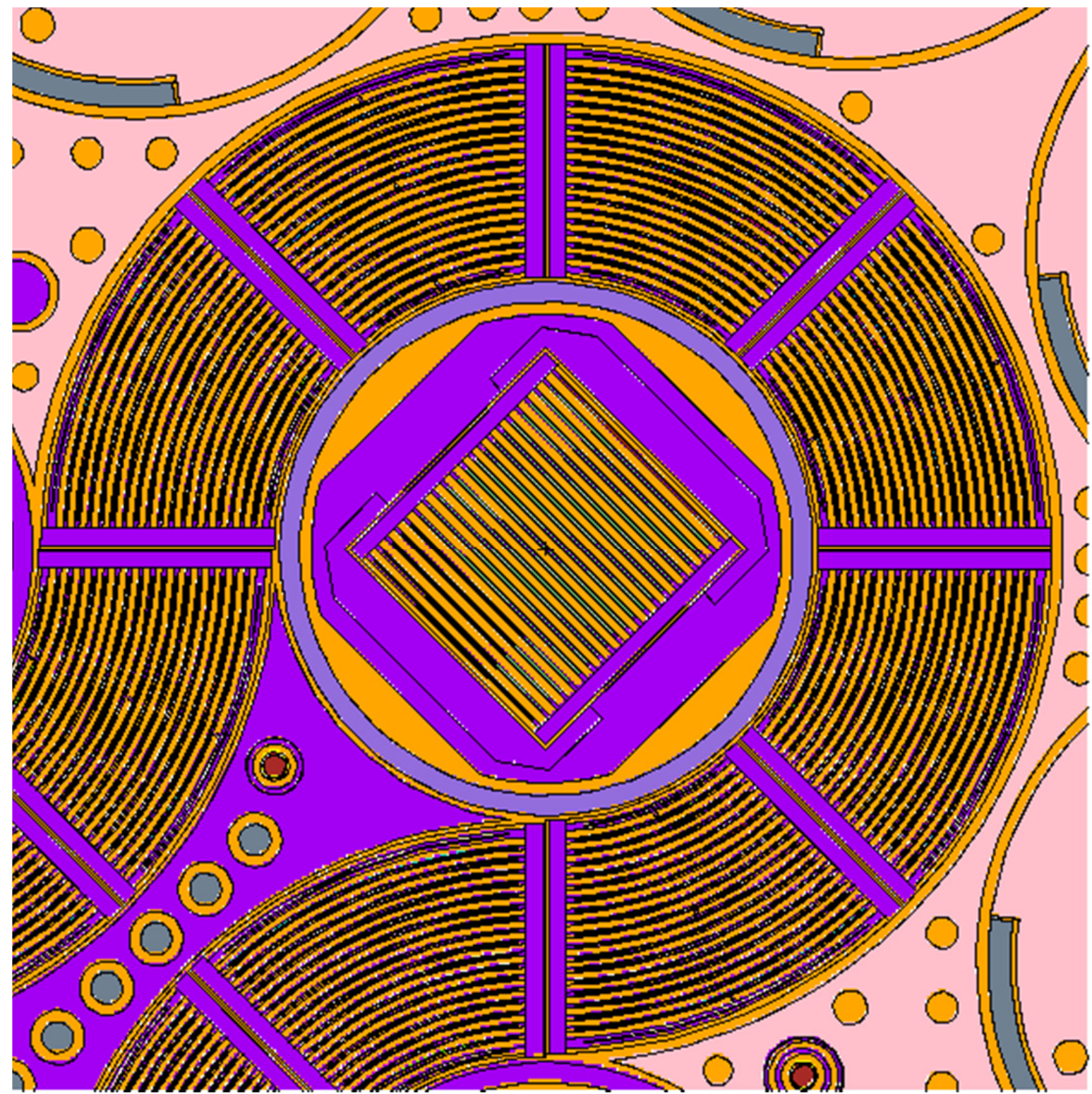

Figure 4. MCNP Model of the KJRR-FAI experiment in the NEFT near core centerline. 
ECAR-2705

Rev. 0
Physics Analysis to Support Advanced Test Reactor Critical Facility Testing of the KJRR-FAI Experiment

Holder

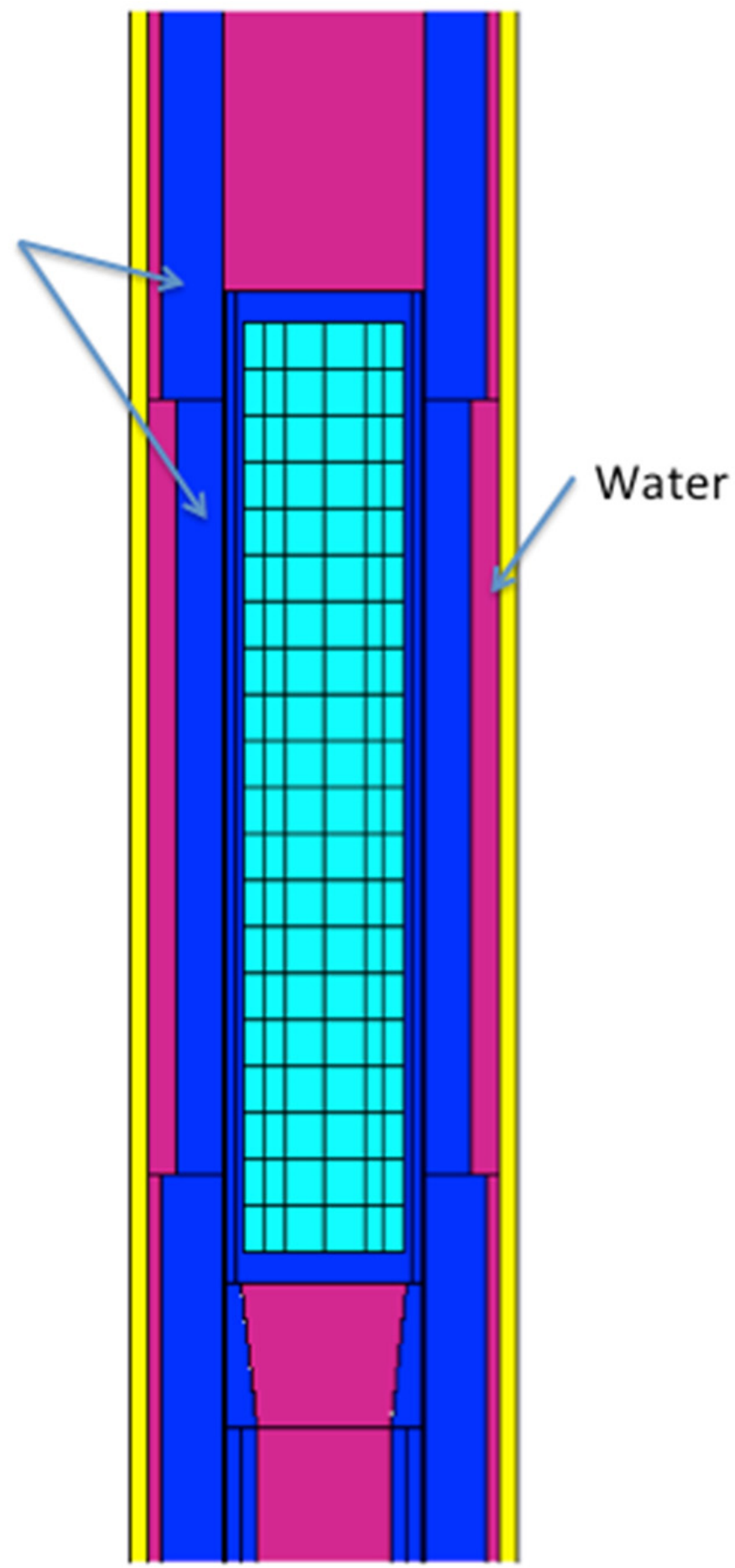

Figure 5. Axial view of the KJRR-FAl experiment. 
ECAR-2705

Rev. 0

\subsection{KJRR Fuel Plate Data}

A summary of the fuel compositions and atom densities used in the MCNP model are summarized in Table 3 and Table 4, respectively. Each of the fuel plates was modeled using nominal dimensions. The Si contained in the fuel meat was neglected in these simulations.

Table 3. Material compositions for KJRR fuel meat.

\begin{tabular}{|c|c|c|c|c|c|c|c|c|}
\hline & \multicolumn{7}{|c|}{ Fuel Meat } \\
\hline Plates & Width $(\mathrm{mm})$ & Length $(\mathrm{mm})$ & Thickness $(\mathrm{mm})$ & $\begin{array}{c}\text { Volume } \\
(\mathrm{cc})\end{array}$ & U Mass (g) & U-235 Mass (g) & Mo Mass (g) & Al Mass (g) \\
\hline 1,21 & 62 & 600 & 0.51 & 18.972 & 123.3 & 24.36 & 9.6 & 30.4 \\
\hline $2-20$ & 62 & 600 & 0.51 & 18.972 & 151.8 & 29.98 & 11.8 & 25.6 \\
\hline
\end{tabular}

Table 4. KJRR atom densities (atoms/b-cm).

\begin{tabular}{|c|c|c|c|c|c|}
\hline Plates & U-235 & U-238 & Mo & Al & Total \\
\hline 1,21 & $3.2891 \mathrm{E}-03$ & $1.3196 \mathrm{E}-02$ & $3.1701 \mathrm{E}-03$ & $3.5816 \mathrm{E}-02$ & $5.5471 \mathrm{E}-02$ \\
\hline $2-20$ & $4.0481 \mathrm{E}-03$ & $1.6241 \mathrm{E}-02$ & $3.9017 \mathrm{E}-03$ & $3.0174 \mathrm{E}-02$ & $5.4365 \mathrm{E}-02$ \\
\hline
\end{tabular}

\subsection{Calculations and Analysis}

\subsection{MCNP Heat Generation Rate Calculations}

The MCNP type 7 fission energy deposition tally has units of MeV/g per source neutron. The f7:n tally tallies all fission energy generated in the fissile material. The $f 7$ tally results are used to calculate fission HGR values for material compositions.

MCNP reports tally results normalized per source particle. The heating normalization factor (HNF) used to calculate either fission heating or neutron/prompt photon heating due to fission neutrons is given by Equation (1).

$$
\begin{aligned}
& H N F=\left(\frac{2.43 \text { fission neutrons }}{\text { fission }}\right)\left(\frac{\text { fission }}{200 \mathrm{MeV}}\right)\left(\frac{1 \times 10^{6} \mathrm{~W}}{M W}\right) \\
& H N F=1.215 \times 10^{4} \frac{\text { fission neutrons }-W}{M e V-M W}
\end{aligned}
$$

\subsection{Software}

The computer code (MCNP) used to perform this analysis is listed as verified and validated (V\&V'd) software in the INL Enterprise Architecture Repository and are accepted as qualified scientific and 
engineering analysis software. A summary of the INL software quality assurance tracking information is presented in Table 5.

Table 5. INL Qualified Analysis Software Version and Tracking Number

\begin{tabular}{|c|c|c|}
\hline Code Name & Version & $\begin{array}{c}\text { V\&V } \\
\text { Tracking Number }\end{array}$ \\
\hline MCNP & 5 (Release 1.40) & 234166 \\
\hline
\end{tabular}

MCNP has been validated for use at the INL by running the 42 sample problems transmitted on the Radiation Safety Information Computational Center (RSICC) installation CD and comparing the results against the standard results provided on the installation CD [4][5][9]. Additionally, the input model for the ATR criticality benchmark [10] was executed and results identical to the published results were obtained [9]. The computer configurations listed in Table 6 were used to perform the MCNP calculations reported by this ECAR.

Table 6. Computer Configurations for INL Qualified MCNP5 installations

\begin{tabular}{|c|c|c|}
\hline Computer Name & Computer Model & Operating System \\
\hline $\begin{array}{l}\text { fission is an Appro (Xtreme- } \mathrm{X}^{\mathrm{TM}} \\
\text { Supercomputer Series) distributed } \\
\text { memory cluster }\end{array}$ & $\begin{array}{l}\text { Two service nodes acting as login nodes } \\
\text { each with: } \\
\text { - Two } 8 \text { core } 2.4 \mathrm{GHz} \text { AMD Opteron } \\
\text { (6136) processors } \\
\text { - } 32 \mathrm{~GB} \text { of shared memory ( } 2 \mathrm{~GB} / \text { core) } \\
391 \text { compute blades with: } \\
\text { - Four } 8 \text { core } 2.4 \mathrm{GHz} \text { AMD Opteron } \\
\text { (6136) processors per blade ( } 32 \\
\text { cores/node and } 12512 \text { cores total) } \\
\text { - } 64 \mathrm{~GB} \text { of shared memory per node ( } 2 \\
\text { GB/core) } \\
\text { QDR InfiniBand interconnect network }\end{array}$ & $\begin{array}{l}\text { RedHat Linux } \\
\text { Enterprise Server } \\
5.7\end{array}$ \\
\hline
\end{tabular}

\subsection{Analysis Results}

\subsection{Experiment Reactivity Worth}

The reactivity worth of the KJRR-FAl experiment was calculated using the 19-plate MCNP ATRC model with 40 fresh fuel elements as described above. Five different cases were modeled to determine the reactivity worth of the KJRR-FAI experiment relative to a water-filled flux trap. The first case modeled a water-filled flux trap, as a reference condition. The second consisted of the KJRR-FAI hardware excluding the inner basket and without the KJRR-FAl element. The third case represents the KJRR-FAI element modeled to determine the full worth of the experiment relative to the water filled condition. The forth case consists of a Large Irradiation Housing Assembly (LIHA) with 14 Al fillers and 9 LSA Cobalt 
ECAR-2705

Rev. 0

capsules. The Al fillers were located in Positions 1, 2, 7, 8, 9, 14, 15, 16, 17, 18, 19, 20, 21, and 22.

The LSA Cobalt was located in Positions 3, 4, 5, 6, 10, 11, 12, 13, and 23. The LIHA with Al fillers and LSA Cobalt capsules will provide a backup for the KJRR-FAl experiment, although its use will require a separate Core Safety Assurance Package with a different fuel load. The fifth case includes 12 flux wands in the KJRR-FAl element and is discussed in more detail below. The results for the reactivity cases are presented in Table 7, using a beta-effective of 0.0072 [3]. The OSCC position for each case was maintained at 45 degrees. In addition, the estimated NE Lobe power (including KJRR) relative to $250 \mathrm{~W}$ is provided as well. Note that the reactivity worth of the experiment can shift as the result of lobe power.

Table 7. Calculated reactivity worth of the KJRR-FAI Experiment.

\begin{tabular}{|c|c|c|c|c|c|}
\hline Case & File Name & Keff & $2 \sigma$ & $\begin{array}{c}\text { Worth } \\
\text { Relative to } \\
\text { Water Filled } \\
\text { Flux Trap (\$) }\end{array}$ & $\begin{array}{c}\text { Relative NE } \\
\text { Lobe Power } \\
\text { (Watts) }\end{array}$ \\
\hline $\begin{array}{c}\text { Water Filled } \\
\text { Flux Trap }\end{array}$ & newf.o & 0.97892 & 0.00006 & 0.00 & 31.5 \\
\hline $\begin{array}{c}\text { KJRR Outer } \\
\text { Basket with no } \\
\text { KJRR }\end{array}$ & kj45wf.o & 0.98037 & 0.00008 & 0.21 & 35.0 \\
\hline $\begin{array}{c}\text { KJRR } \\
\text { Kj453b.0 }\end{array}$ & 0.99832 & 0.00005 & 2.76 & 68.9 \\
\hline $\begin{array}{c}\text { LIHA with 9 } \\
\text { and 14 Al fillers }\end{array}$ & neliha.o & 0.97769 & 0.00007 & -0.18 & 27.6 \\
\hline $\begin{array}{c}\text { KJRR } \\
\text { experiment } \\
\text { with 12 flux } \\
\text { wands in KJRR }\end{array}$ & kj45p1.0 & 0.99794 & 0.00005 & 2.70 & 68.3 \\
\hline \begin{tabular}{l} 
* Relative to a total ATRC core power of 250 Watts \\
\hline
\end{tabular}
\end{tabular}

Additional calculations were performed to determine the critical shim position with the KJRR-FAI experiment inserted. The known critical eigenvalue for various cases modeled in ATRC is approximately 0.989 [6]. Assuming this to be the critical eigenvalue for the ATRC model, the cases with a balanced 35 and 40 degrees OSCC position yielded eigenvalues of 0.98882 and 0.99332 , respectively. This has resulted in a differential worth of $0.127 \$ /$ degree. Therefore, the estimated balanced critical shim position for the KJRR-FAI experiment will be approximately 35.2 degrees. 
An additional case to determine the reactivity worth of the flux wands in the KJRR-FAl experiment was modeled. The simulation determined the worth of 12 flux wands in the experiment to be worth $-0.06 \$$. The flux wands were modeled as a homogeneous mixture of water and polyethylene with a water volume fraction of $64.3 \%$ (Dwg 604595). The critical shim position for this case will be approximately 36.0 degrees.

\subsection{Power Distribution}

Reference [11] Appendix $B$ determined the amount of energy required to raise the temperature of 40 ATR fuel elements from $300 \mathrm{~K}$ to $855 \mathrm{~K}$ where cladding failure occurs is $120 \mathrm{MJ}$. Assuming a peaking factor of 4 will limit the total energy deposited in the fuel to $30 \mathrm{MJ}$, which will prevent cladding damage at the hot spot in the reactor fuel. A safety factor of 2 has been applied via neutron level setpoints to ensure that from a reactivity insertion accident, the increase in temperature of the hot spot of fuel will be below the melting temperature of the cladding. Thus, the assumptions supporting the ATRC thermalhydraulics analysis assume a peak to average power density ratio of 4-to-1 that must be confirmed for a given experiment.

The KJRR-FAI fuel is an aluminum-clad U-Mo/Al dispersion fuel. The cladding is similar to the ATR fuel element cladding and exhibits the same thermal properties as the ATR fuel element cladding.

Therefore, the thermal analysis for ATR fuel and the analysis to document the melting point of ATR fuel can be applied to the KJRR-FAl experiment. Maintaining the power density limits in the ATR fuel as well as KJRR-FAI ensures that the KJRR-FAl experiment will not melt during the postulated accident transients identified in SAR-192 [2] provided the total energy deposition in the core is less than $15 \mathrm{MJ}$. Therefore, the SAR-192 accident analysis for heat-up of ATR fuel elements (energy deposition and application of the $15 \mathrm{MJ}$ limit) also demonstrates that the KJRR-FAI experiment does not melt during postulated transients [12].

The power distribution in the ATRC fuel and KJRR-FAI were calculated in MCNP using the 19 plate model. The calculated power and power density for each element and the KJRR-FAl experiment were calculated using the MCNP ATRC model. The powers in each element (including KJRR) were normalized to a reactor power of $250 \mathrm{~W}$. The results are presented in Table 8 . The peak average element power density occurs in the KJRR-FAI experiment with an element peak to average power density of 2.54. As a result of this, the KJRR-FAI experiment was nodalized to capture peaking within the element itself. The element was divided into a 20 axial regions to capture axial peaking factors within the element. The calculated maximum peaking factor as presented in Appendix $A$ is 1.31 .

Multiplying the maximum power density of 2.54 by the axial peaking factor yields a maximum power density ratio of 3.33 , which is below the assumed value of 4.0 . As discussed above, the power density 
ECAR-2705

Rev. 0
Physics Analysis to Support Advanced Test Reactor Critical

Facility Testing of the KJRR-FAI Experiment

ratio is correlated to the maximum allowed energy deposition in the core, which is $15 \mathrm{MJ}$ assuming a safety factor of 2 [11]. Therefore, the $15 \mathrm{MJ}$ acceptance limit remains applicable to postulated reactivity insertion transients in order to demonstrate that failure of the ATRC fuel or KJRR-FAl experiment does not occur.

Table 8. Calculated power distribution in ATRC fuel elements and KJRR-FAI (normalized to 250 Watts).

\begin{tabular}{|c|c|c|c|c|}
\hline Element & $\begin{array}{c}\text { Element } \\
\text { Power (W) }\end{array}$ & $\begin{array}{c}\text { Element } \\
\text { Volume (cc) }\end{array}$ & $\begin{array}{l}\text { Power } \\
\text { Density } \\
\text { (W/cc) }\end{array}$ & $\begin{array}{c}\text { Peak to } \\
\text { Average } \\
\text { Power } \\
\text { Density }\end{array}$ \\
\hline 1 & 6.29 & 792.99 & 7.93E-03 & 1.02 \\
\hline 2 & 7.54 & 792.99 & $9.51 \mathrm{E}-03$ & 1.22 \\
\hline 3 & 8.10 & 792.99 & $1.02 \mathrm{E}-02$ & 1.31 \\
\hline 4 & 7.65 & 792.99 & $9.65 \mathrm{E}-03$ & 1.24 \\
\hline 5 & 6.95 & 792.99 & 8.76E-03 & 1.13 \\
\hline 6 & 6.79 & 792.99 & $8.56 \mathrm{E}-03$ & 1.10 \\
\hline 7 & 7.77 & 792.99 & $9.80 \mathrm{E}-03$ & 1.26 \\
\hline 8 & 8.39 & 792.99 & $1.06 \mathrm{E}-02$ & 1.36 \\
\hline 9 & 7.84 & 792.99 & $9.88 \mathrm{E}-03$ & 1.27 \\
\hline 10 & 6.59 & 792.99 & $8.32 \mathrm{E}-03$ & 1.07 \\
\hline 11 & 6.21 & 792.99 & $7.83 \mathrm{E}-03$ & 1.01 \\
\hline 12 & 6.12 & 792.99 & 7.72E-03 & 0.99 \\
\hline 13 & 5.75 & 792.99 & $7.25 \mathrm{E}-03$ & 0.93 \\
\hline 14 & 4.41 & 792.99 & $5.56 \mathrm{E}-03$ & 0.71 \\
\hline 15 & 3.53 & 792.99 & $4.46 \mathrm{E}-03$ & 0.57 \\
\hline 16 & 3.57 & 792.99 & $4.50 \mathrm{E}-03$ & 0.58 \\
\hline 17 & 4.58 & 792.99 & $5.77 \mathrm{E}-03$ & 0.74 \\
\hline 18 & 6.21 & 792.99 & $7.83 \mathrm{E}-03$ & 1.01 \\
\hline 19 & 6.56 & 792.99 & $8.27 \mathrm{E}-03$ & 1.06 \\
\hline 20 & 6.54 & 792.99 & $8.25 \mathrm{E}-03$ & 1.06 \\
\hline 21 & 6.95 & 792.99 & $8.77 \mathrm{E}-03$ & 1.13 \\
\hline 22 & 8.59 & 792.99 & $1.08 \mathrm{E}-02$ & 1.39 \\
\hline 23 & 8.99 & 792.99 & $1.13 \mathrm{E}-02$ & 1.46 \\
\hline 24 & 7.78 & 792.99 & $9.81 \mathrm{E}-03$ & 1.26 \\
\hline 25 & 6.57 & 792.99 & $8.29 \mathrm{E}-03$ & 1.06 \\
\hline 26 & 6.50 & 792.99 & $8.19 \mathrm{E}-03$ & 1.05 \\
\hline 27 & 7.49 & 792.99 & $9.44 \mathrm{E}-03$ & 1.21 \\
\hline 28 & 8.24 & 792.99 & $1.04 \mathrm{E}-02$ & 1.34 \\
\hline 29 & 7.99 & 792.99 & $1.01 \mathrm{E}-02$ & 1.29 \\
\hline 30 & 6.28 & 792.99 & $7.92 \mathrm{E}-03$ & 1.02 \\
\hline 31 & 5.54 & 792.99 & $6.99 \mathrm{E}-03$ & 0.90 \\
\hline
\end{tabular}


ECAR-2705

Rev. 0
Physics Analysis to Support Advanced Test Reactor Critical Facility Testing of the KJRR-FAI Experiment

\begin{tabular}{|c|c|c|c|c|}
\hline Element & $\begin{array}{c}\text { Element } \\
\text { Power }(\mathrm{W})\end{array}$ & $\begin{array}{c}\text { Element } \\
\text { Volume }(\mathrm{cc})\end{array}$ & $\begin{array}{c}\text { Power } \\
\text { Density } \\
(\mathrm{W} / \mathrm{cc})\end{array}$ & $\begin{array}{c}\text { Peak to } \\
\text { Average } \\
\text { Power } \\
\text { Density }\end{array}$ \\
\hline 32 & 4.90 & 792.99 & $6.17 \mathrm{E}-03$ & 0.79 \\
\hline 33 & 4.28 & 792.99 & $5.40 \mathrm{E}-03$ & 0.69 \\
\hline 34 & 2.94 & 792.99 & $3.71 \mathrm{E}-03$ & 0.48 \\
\hline 35 & 2.05 & 792.99 & $2.59 \mathrm{E}-03$ & 0.33 \\
\hline 36 & 2.17 & 792.99 & $2.73 \mathrm{E}-03$ & 0.35 \\
\hline 37 & 2.90 & 792.99 & $3.66 \mathrm{E}-03$ & 0.47 \\
\hline 38 & 4.20 & 792.99 & $5.30 \mathrm{E}-03$ & 0.68 \\
\hline 39 & 4.84 & 792.99 & $6.11 \mathrm{E}-03$ & 0.78 \\
\hline 40 & 5.52 & 792.99 & $6.96 \mathrm{E}-03$ & 0.89 \\
\hline KJRR-FAI & 7.88 & 398.41 & $1.98 \mathrm{E}-02$ & 2.54 \\
\hline Total & 250.0 & 32118.01 & $7.784 \mathrm{E}-3$ & \\
\hline
\end{tabular}

\subsection{Moderator Density and Temperature Coefficient of Reactivity}

The moderator density coefficient of reactivity was calculated using the 19 plate ATRC MCNP model. The calculations were performed by adjusting the density of water in the fuel channels of the KJRR-FAl experiment and determining the changes in reactivity. Neutron cross-section changes for water as a function of temperature in the range of transients experienced in ATR or ATRC is minimal and was not modeled. Thus, the moderator temperature coefficient of ATR and ATRC is demonstrated by density changes in the water. The calculated results for the KJRR-FAI experiment are presented in 
Table 9. Water density was determined for several water temperatures at a pressure of $14.5 \mathrm{psi}(0.1$ MPa) [13].

The moderator temperature coefficient for the KJRR-FAl experiment is negative. The flux traps in ATR and ATRC typically have a positive moderator temperature coefficient that results in limits imposed on ATR due to cascading concerns. Cascading occurs as the result of a reactivity insertion accident causing heat-up of the moderator in the flux trap. The minimal heating due to the low power of the ATRC does not create a significant issue associated with cascading. However, for completeness, the moderator temperature coefficients of reactivity are calculated for the KJRR-FAl experiment in the ATRC. The moderator temperature coefficient for reactivity is approximately $-0.00056 \$ /^{\circ} \mathrm{F}$ $[-0.00056=-0.071 /(194-68)]$. 
ECAR-2705

Rev. 0

Table 9. Calculated moderator temperature coefficients of reactivity for the KJRR-FAl experiment.

\begin{tabular}{|c|c|c|c|}
\hline $\begin{array}{c}\text { Water } \\
\text { Density } \\
(\mathrm{g} / \mathrm{cC})\end{array}$ & $\begin{array}{c}\text { Water } \\
\text { Temperature } \\
\left({ }^{\circ} \mathrm{F}\right)\end{array}$ & keff & $\begin{array}{c}\text { Reactivity } \\
\text { Worth }(\$)\end{array}$ \\
\hline 0.9980 & 68 & 0.99827 & 0.000 \\
\hline 0.9881 & 122 & 0.99818 & -0.013 \\
\hline 0.9653 & 194 & 0.99776 & -0.071 \\
\hline
\end{tabular}

In order to support measurements of the void worth and temperature coefficient of reactivity in the KJRR-FAl experiment, Teflon wands will be placed in the channels of the KJRR-FAl experiment. The water volume fraction of a channel containing a Teflon wand is $45.6 \%$ (Dwg 604596). Table 10 summarizes the results relative to the KJRR-FAl experiment. Assuming the shim worth curve documented in

Table 12 (indicating $0.127 \$$ /degree of balanced OSCC rotation) and a critical position of 35.2 degrees without Teflon wands, the estimated balanced critical position for each case will be approximately 38.2 degrees for 10 Teflon wands and 40.8 degrees for 20 Teflon wands. The purpose of the measurements for void worth is to demonstrate the positive moderator density coefficient. A positive moderator density coefficient corresponds to a negative temperature coefficient in the event that a voiding accident was to occur due to temperature changes in the core. There is no intention to credit the magnitude of the negative temperature coefficient in safety calculations for the KJRR-FAI experiment, rather to credit the negative feedback effects. Experiment lobe temperature coefficients are typically positive in ATR and the negative temperature coefficient associated with the KJRR-FAI experiment complies with limits associated with cascading in ATR.

Table 10. Reactivity worth of Teflon wands in the KJRR-FAl experiment.

\begin{tabular}{|c|c|c|c|c|}
\hline & $\begin{array}{c}\text { Number of } \\
\text { Wands }\end{array}$ & $\begin{array}{c}\text { Average water } \\
\text { density in } \\
\text { element }(\mathrm{g} / \mathrm{cc})\end{array}$ & keff & $\begin{array}{c}\text { Reactivity } \\
\text { Worth }(\$)\end{array}$ \\
\hline kj453b.o & 0 & 1.000 & 0.99832 & 0.000 \\
\hline kj45t1.o & 10 & 0.728 & 0.99559 & -0.381 \\
\hline kj45t2.o & 20 & 0.456 & 0.99326 & -0.708 \\
\hline
\end{tabular}


ECAR-2705

Rev. 0

\subsection{KJRR-FAI Safety Rod Worth}

The ATRC safety rod worths were calculated in MCNP using the 19 plate model. Calculations were performed to determine the effects of the KJRR-FAI experiment on the worth of the ATRC safety rods. The calculations were performed to determine if the insertion of the KJRR-FAl experiment will affect the safety rod worth as required in the safety analysis to prevent core damage from postulated accident conditions. Scoping calculations were performed and determined that the KJRR-FAl experiment due to the fuel loading reduces the safety rod worth for safety rods in the south and west quadrants of ATRC. The reduction in safety rod worth for a normal core loading reduces the total rod worth, assuming the most reactive safety rod is stuck and does not insert, to less than the $5.3 \$$ of shutdown worth required by Section 3.8.8 of SAR-192 [2]. Therefore, numerous configurations were examined to determine how to increase safety rod worth.

The configuration of the ATRC was determined to meet the safety basis requirements using the loading discussed above. The loading includes the use of non-borated 7F fuel elements in the southwest lobe of the reactor. The increased loading draws the reactor power to the SW lobe, increasing the safety rod worth of the W, SW, and S safety rods. The results of this configuration for different combinations of stuck safety rods are presented in Error! Reference source not found.. The highest worth safety rod is the $E$ safety rod. Assuming this rod is stuck during a transient, the shutdown worth of the remaining 4 rods is $6.27 \$$, which is greater than the minimum required safety rod worth.

The total worth of the safety rods reported in SAR-192 Table 3-1 Reference [2] is a nominal $10.8 \$$ with a maximum reactivity insertion rate from simultaneous withdrawal of $0.036 \$ / \mathrm{sec}$. The nominal reactivity worth of the safety rods with KJRR-FAI experiment is $9.59 \$$. The reduced worth of the safety rods due to the presence of the KJRR-FAl experiment will also result in a reduction of the insertion rate during simultaneous withdrawal.

Table 11. Calculated safety rod worths for the KJRR-FAI experiment and LIHA in the NEFT.

\begin{tabular}{|c|c|c|}
\hline & \multicolumn{2}{|c|}{ KJRR } \\
\hline $\begin{array}{c}\text { Stuck Safety Rod } \\
\begin{array}{c}\text { No safety rods } \\
\text { inserted }\end{array}\end{array}$ & $\begin{array}{c}\text { Keff } \\
\text { Worth (\$) }\end{array}$ \\
\hline None & 0.99832 & 0.00 \\
\hline North - N & 0.95112 & -6.90 \\
\hline East - E & 0.95529 & -6.27 \\
\hline Southwest - SW & 0.94168 & -8.37 \\
\hline South - S & 0.94323 & -8.13 \\
\hline West - W & 0.93912 & -8.77 \\
\hline
\end{tabular}


ECAR-2705

Rev. 0

In order to support previous operations, a set of calculations was performed for the insertion of all safety rods for the 1994 Core Internals Changeout (CIC) configuration. The safety rods were measured during this set of physics testing and reported in Reference [14]. The calculated safety rod worth for insertion of all safety rods was $-10.83 \$$. The measured safety rod worth was $-10.94 \$$. Therefore, the MCNP model of ATRC provides a reasonable estimate of safety rod worth.

\subsection{KJRR-FAI OSCC Worth Curves and Neck Shim Worths}

The ATRC OSCC worth curve was calculated in MCNP using the 19 plate model. The OSCC worth curve was determined by evaluating the change in reactivity by running several cases with the OSCC at different positions. The total OSCC worth curve is summarized in

Table 12 and shown in Figure 6. The OSCC worth with the KJRR-FAl experiment is slightly higher than for the $1994 \mathrm{CIC}$ configuration, which is assumed to still represent the ATRC configuration without the KJRR-FAl experiment. The loading for the ATRC 1994 CIC configuration (94-2 configuration) and measurements are documented in Reference [14].

Table 12. Calculated OSCC worth for the KJRR-FAI and LIHA experiment in the NEFT.

\begin{tabular}{|c|c|c|c|c|}
\hline Degrees & $\begin{array}{c}1994 \text { CIC } \\
\text { keff }\end{array}$ & $\begin{array}{c}1994 \text { OSCC } \\
\text { Worth }(\$)\end{array}$ & KJRR keff & $\begin{array}{c}\text { KJRR OSCC } \\
\text { Worth }(\$)\end{array}$ \\
\hline 0 & 0.94500 & 0.000 & 0.97108 & 0.000 \\
\hline 5 & 0.94589 & 0.138 & 0.97210 & 0.150 \\
\hline 10 & 0.94703 & 0.315 & 0.97369 & 0.383 \\
\hline 15 & 0.94850 & 0.542 & 0.97573 & 0.682 \\
\hline 20 & 0.95043 & 0.840 & 0.97820 & 1.041 \\
\hline 25 & 0.95264 & 1.179 & 0.98119 & 1.474 \\
\hline 30 & 0.95551 & 1.617 & 0.98469 & 1.977 \\
\hline 35 & 0.95855 & 2.078 & 0.98882 & 2.566 \\
\hline 40 & 0.96204 & 2.603 & 0.99332 & 3.202 \\
\hline 45 & 0.96585 & 3.173 & 0.99832 & 3.903 \\
\hline 50 & 0.97022 & 3.820 & 1.00360 & 4.634 \\
\hline 55 & 0.97473 & 4.483 & 1.00926 & 5.411 \\
\hline 60 & 0.97958 & 5.188 & 1.01493 & 6.179 \\
\hline 65 & 0.98434 & 5.874 & 1.02078 & 6.964 \\
\hline 70 & 0.98909 & 6.551 & 1.02641 & 7.710 \\
\hline 75 & 0.99414 & 7.265 & 1.03207 & 8.452 \\
\hline 80 & 0.99869 & 7.901 & 1.03751 & 9.158 \\
\hline 85 & 1.00303 & 8.503 & 1.04254 & 9.804 \\
\hline 90 & 1.00747 & 9.113 & 1.04744 & 10.427 \\
\hline
\end{tabular}


ECAR-2705

Rev. 0
Physics Analysis to Support Advanced Test Reactor Critical

Facility Testing of the KJRR-FAI Experiment

\begin{tabular}{|c|c|c|c|c|}
\hline Degrees & $\begin{array}{c}1994 \mathrm{CIC} \\
\text { keff }\end{array}$ & $\begin{array}{c}1994 \text { OSCC } \\
\text { Worth (\$) }\end{array}$ & $\begin{array}{c}\text { KJRR keff } \\
\text { KJRR OSCC } \\
\text { Worth (\$) }\end{array}$ \\
\hline 95 & 1.01147 & 9.658 & 1.05177 & 10.973 \\
\hline 100 & 1.01517 & 10.159 & 1.05596 & 11.497 \\
\hline 105 & 1.01873 & 10.637 & 1.05973 & 11.965 \\
\hline 110 & 1.02173 & 11.037 & 1.06310 & 12.380 \\
\hline 115 & 1.02444 & 11.397 & 1.06607 & 12.744 \\
\hline 120 & 1.02691 & 11.723 & 1.06871 & 13.066 \\
\hline 125 & 1.02902 & 12.000 & 1.07095 & 13.338 \\
\hline 130 & 1.03086 & 12.241 & 1.07292 & 13.576 \\
\hline 135 & 1.03241 & 12.444 & 1.07451 & 13.767 \\
\hline 140 & 1.03366 & 12.606 & 1.07594 & 13.939 \\
\hline 145 & 1.03463 & 12.732 & 1.07692 & 14.057 \\
\hline 150 & 1.03550 & 12.845 & 1.07773 & 14.153 \\
\hline
\end{tabular}

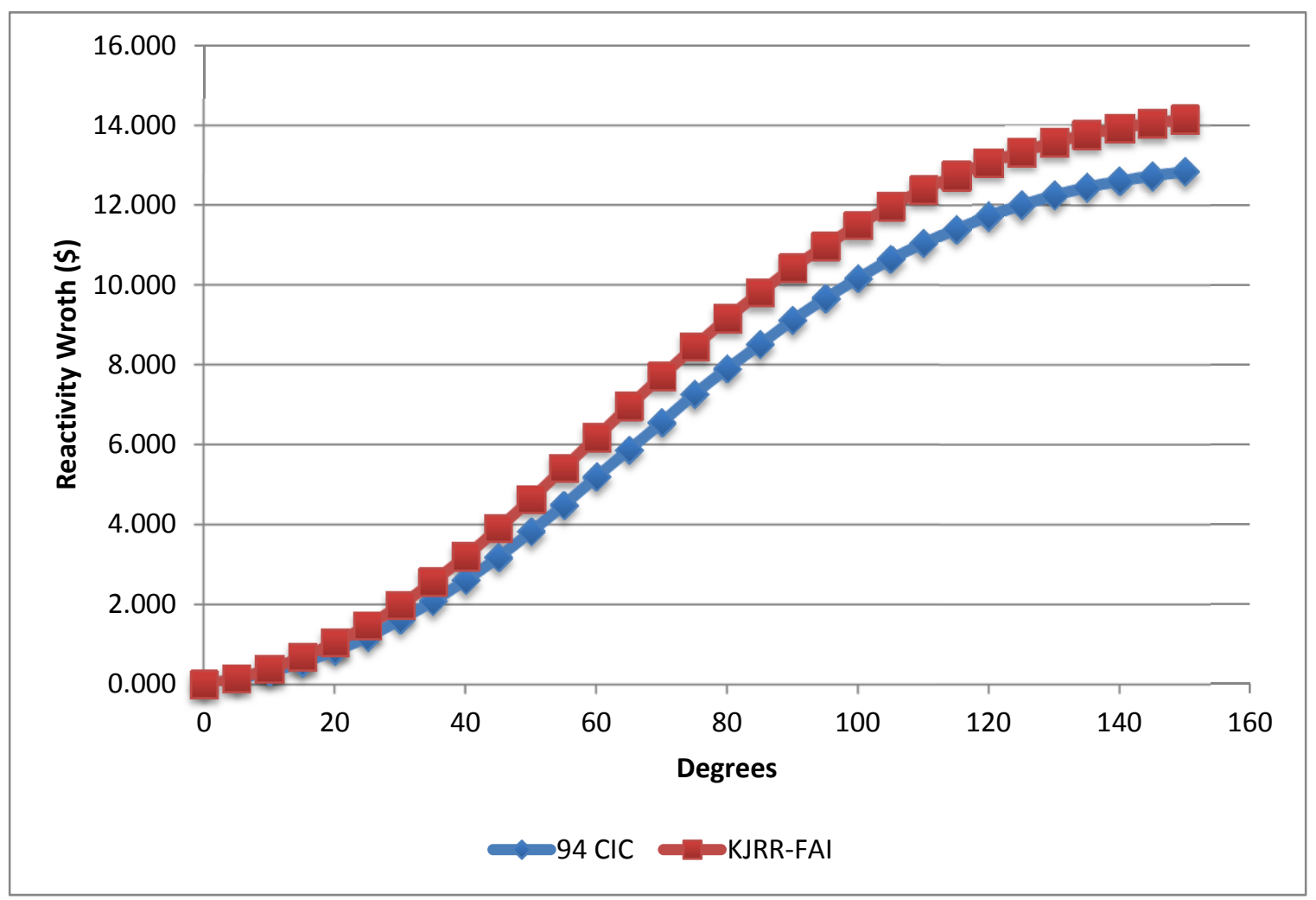

Figure 6. OSCC worth curve for the KJRR-FAI and LIHA in the NEFT. 
The KJRR-FAI experiment will have an effect on the NE OSCCs. During the measurement of the OSCCs [15], the shims are withdrawn in pairs of 2 and inserted in pairs of 2 to maintain the power balance. The OSCC worth curves for the N3 and N4 OSCCs are presented in Figure 7 for different E1 and E2 shim positions. The OSCC worth curves for E1 and E2 with different N3 and N4 positions are presented in Figure 8. The remaining OSCC positions were assumed to be balanced at 40 degrees. Based on the MCNP calculations, it is anticipated that the NE shims measurements may only be able to achieve an OSCC withdrawal of 50 to 55 degrees. Withdrawal of the OSCCs further will not be possible due to the excess reactivity that would be generated by this configuration. The OSCCs other than the NE shims do not have sufficient worth from the balanced critical position to hold down reactivity as the NE shims are rotated out to their outer limits. The actual validation of OSCC worth curves will be evaluated following the experiment. Additional measures may achieve slightly more withdrawal; however, the intent of these measurements is to validate the analytical models used to support the irradiation. As can be seen by the figures, the OSCC worth curves will be dependent upon the position of the opposite pair of shims. The total worth of the NE bank is estimated to be between $5.7 \$$ and $7.3 \$$.

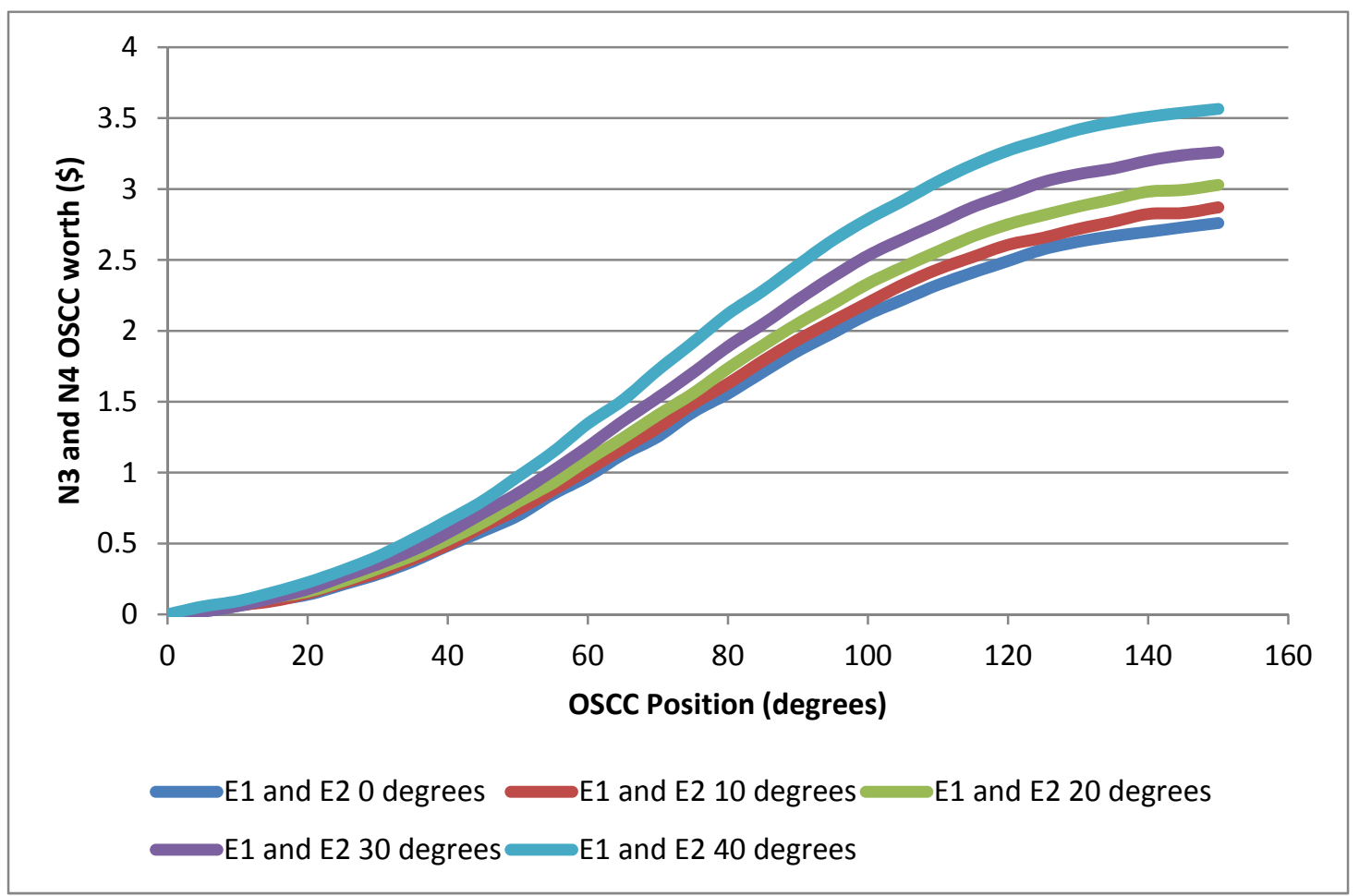

Figure 7. OSCC worth curve for shims N3 and N4. 

Facility Testing of the KJRR-FAI Experiment

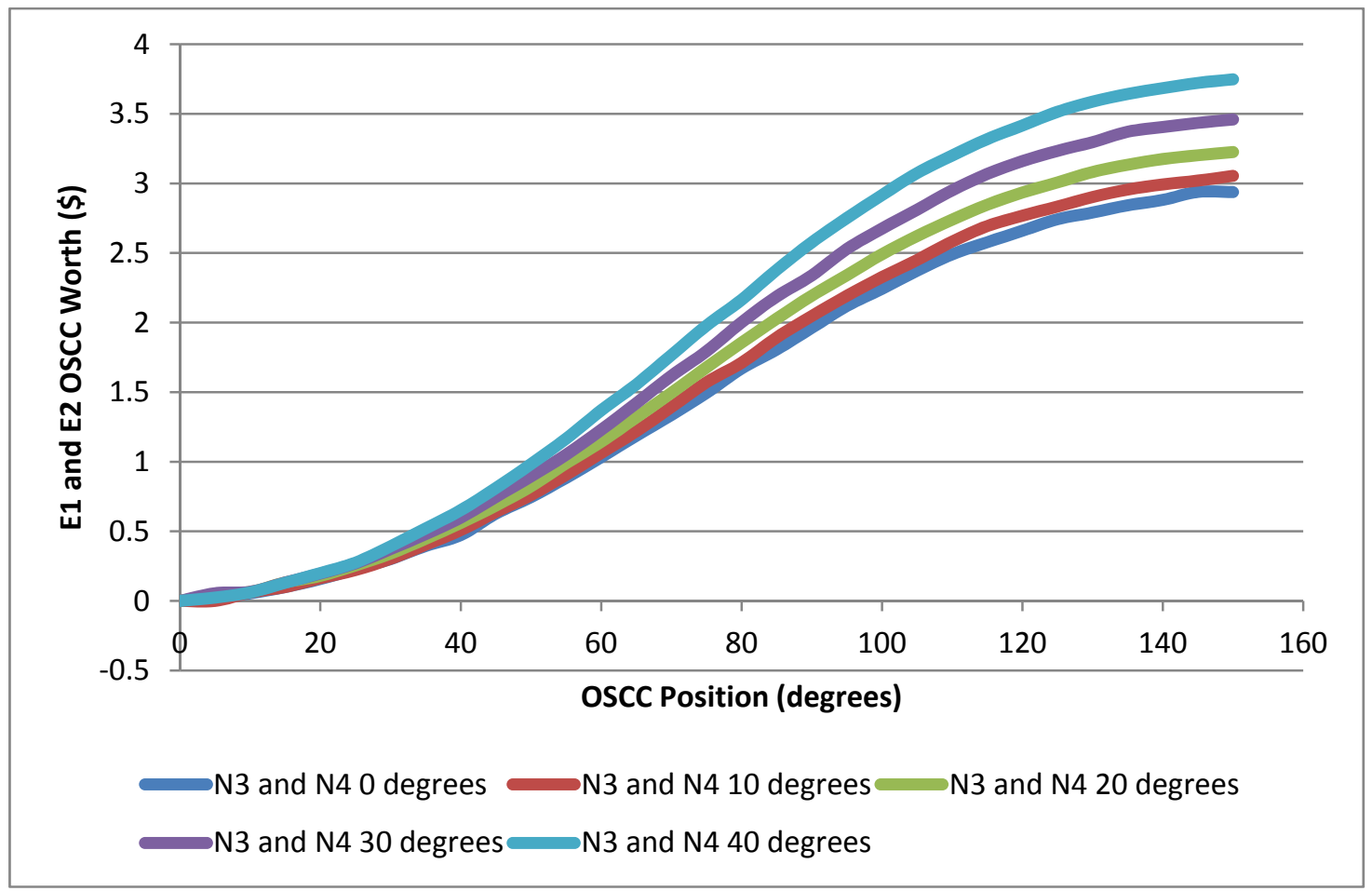

Figure 8. OSCC worth curve for shims E1 and E2.

The remaining OSCCs worth curves are presented in Figure 9. The calculations assumed the other OSCC banks were maintained at a position of 40 degrees while the 2 pairs of interest were rotated out simultaneously. This configuration would not maintain criticality in ATRC. However, the calculation provides an estimate as to the worth of these shim banks.

Once the KJRR-FAl experiment is inserted in ATR, the presence of depleted ATR driver fuel will result in a decrease in the OSCC worth for the NE shims. Measurements of the OSCCs in the NE lobe of ATR should be performed as part of start-up operations to confirm estimates of ATR OSCC worth. 


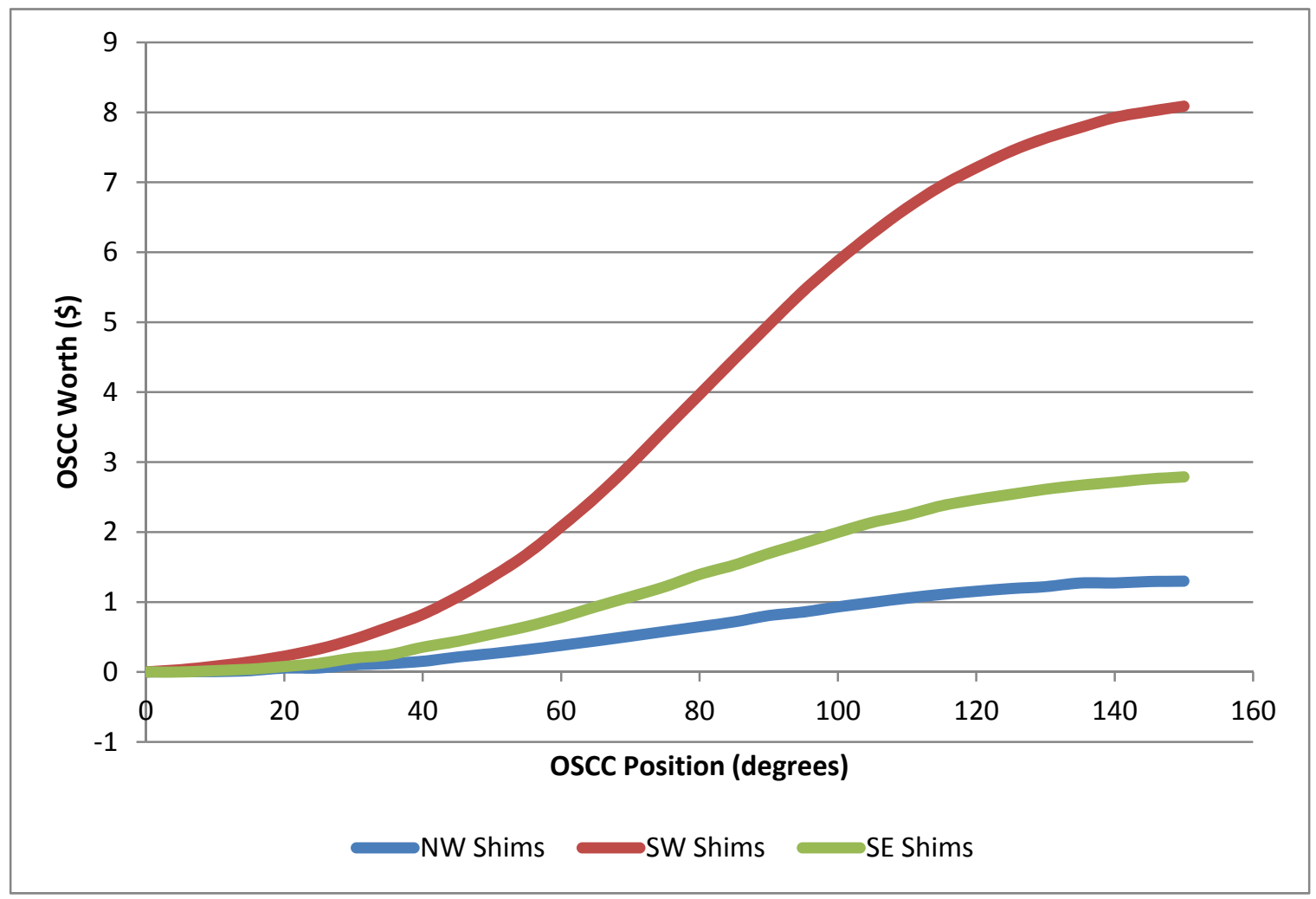

Figure 9. OSCC shim worth curve for NW, SW, and SE shim banks.

The presence of the KJRR-FAl experiment may have a significant impact on the worth of the ATRC neck shims. It is not anticipated that the ATRC neck shim worths will be measured in ATRC since the neck shims in ATR are greatly affected by lobe power that will not be simulated with the proposed ATRC configuration. The use of 40 fresh fuel elements in ATRC creates power splits that are not representative of ATR loaded with depleted fuel and therefore, will not be measured. However, control shim withdrawal accidents need to be compared to those in the safety basis. The calculated relative lobe power in the NEFT is $68.9 \mathrm{MW}$, which dominates the other four lobes in ATRC. The neck shim worth for the NE lobe will have a higher worth than the corresponding neckshims in the other three lobes containing neck shims. The calculated reactivity worth of the 6 neck shims in ATRC are reported in Table 13. The table provides the worth of each individual rod as they are removed from the outer most rod (NE-6) inward toward the inner most (NE-1). The highest worth neck shim is NE-5 with a worth of $0.472 \$$. An additional case modeled the withdrawal of all Position 6 neck shims in ATRC. This has been assumed to be the bounding neck shim withdrawal case for ATRC based on reported reactivity worths of neck shims in Reference [16]. The power split for the ATRC with KJRR results in the neck shims in the NE lobe having the greatest worth with the NE-5 shim enveloping the remaining neck shims. . 
ECAR-2705

Rev. 0
Physics Analysis to Support Advanced Test Reactor Critical Facility Testing of the KJRR-FAI Experiment

Table 13. Calculated reactivity worth of NE neck shims with KJRR.

\begin{tabular}{|c|c|c|c|c|}
\hline File Name & Neck shim & keff & $\begin{array}{c}\text { Group } \\
\text { Worth }\end{array}$ & $\begin{array}{c}\text { Individual } \\
\text { Worth }\end{array}$ \\
\hline kj_35.o: & - & 0.98882 & 0.000 & \\
\hline & NW, NE, & & & \\
Pos_6.o & SW, SE-6 & 0.99683 & 1.129 & $\sim 0.28$ \\
\hline ne6.o: & NE-6 & 0.99163 & 0.398 & 0.398 \\
\hline ne5.o: & NE-5 & 0.99498 & 0.870 & 0.472 \\
\hline ne4.o: & NE-4 & 0.99813 & 1.310 & 0.441 \\
\hline ne3.o: & NE-3 & 1.00137 & 1.760 & 0.450 \\
\hline ne2.o: & NE-2 & 1.00415 & 2.144 & 0.384 \\
\hline ne1.o: & NE-1 & 1.00671 & 2.496 & 0.352 \\
\hline
\end{tabular}

The maximum OSCC worth with the KJRR-FAl experiment is $0.156 \$$ /degree. Per Section 3.8.1 of SAR-192 [2], the maximum withdrawal rate of the OSCC at ATRC is 0.452 angular degrees/sec. Therefore, the maximum reactivity insertion rate of all 16 OSCCs would be $0.071 \$ / \mathrm{sec}$. The SAR-192 (Sections 8.4.6.1, 8.4.7.1 and 8.4.8.1) safety basis analyses assume a maximum reactivity insertion rate of $0.077 \$ / \mathrm{sec}$ for withdrawal of all OSCCs during a reactivity insertion accident; therefore, the OSCC reactivity insertion rate assumed in the accident analyses remains valid The limiting condition 3 reactivity insertion accident assumes withdrawal of all OSCCs and four neck shims. The reactivity worth of the four number 6 neck shims in each lobe without KJRR is $1.20 \$$ or $0.30 \$$ each with a maximum insertion rate of $0.033 \$ / \mathrm{sec}$ for the four withdrawn simultaneously [16]. Conservatively assuming the four neck shims have the same worth as the NE-5, with KJRR, the total worth is $1.89 \$$ or a factor of 1.6 higher than without the KJRR-FAl. Scaling the withdrawal rate of $0.033 \$ / \mathrm{sec}$ by 1.5 results in a maximum withdrawal rate of $0.0519 \$ / \mathrm{sec}$. The total reactivity insertion from this accident is $0.123 \$ / \mathrm{sec}$ $(0.052+0.071 \$ / \mathrm{sec})$. Per Section 8.4.8.1.3 of SAR-192 [2], the maximum reactivity insertion rate, the result of a large in-pile tube blowdown accident, is $0.26 \$ / \mathrm{sec}$. This accident results in a maximum energy deposition of $4.0 \mathrm{MJ}$, which is below the protective criteria of $15 \mathrm{MJ}$ [2]. Therefore, the presence of the KJRR-FAl experiment will not affect the accident conditions assumed in the safety basis for an OSCC withdrawal accident. 


\subsection{References}

[1] N. E. Woolstenhulme, R. B. Nielson, "KJRR-FAI Status Report of Conceptual Design Activities," INL/EXT-13-30857, Rev. 0, December 2013.

[2] "Safety Analysis Report for the Advanced Test Reactor Critical Facility," SAR-192, Revision 15, September 2014.

[3] E. C. Anderson, et al., "ATR Operating Envelope Extension," TR-386, Aerojet Nuclear Company, Engineering Division, May 1973.

[4] MCNP Team, "MCNP 5.1.40 RSICC Release Notes," LA-UR-05-8617, November 10, 2005.

[5] X-5 Monte Carlo Team, "MCNP_A General Monte Carlo N-Particle Transport Code, Version 5," Volume I, LA-UR-03-0245, Los Alamos National Laboratory, April 24, 2003 (Revised 6/30/2004) and Volume II, LA-CP-03-0245, Los Alamos National Laboratory, April 24, 2003 (Revised 6/30/2004) (Vol. II is available with a licensed copy of MCNP).

[6] D. Nigg, "Computational Reactor Physics Methods and Validation Protocols for the Advanced Test Reactor Safety Analysis and Operations," TEV-1753, Rev. 0, June 2014.

[7] T. Nakagawa, et al., "Japanese Evaluated Nuclear Data Library Version 3 Revision-2: JENDL-3.2," Journal of Nuclear Science and Technology, Vol. 32, pp. 1259-1271, December 1995.

[8] "Ki-Jang Research Reactor Fuel Assembly Campaign," FOR-169, Rev. 1, June 2014.

[9] M. A. Lillo, J. R. Mitchell, "Software Management, MCNP Version 5, Release 1.40," INL/INT-08-15171 Rev. 0, August 2010, INL Record Number 234166.

[10] S. S. Kim, B. G. Schnitzler, "Advanced Test Reactor: Serpentine Arrangement of Highly Enriched Water-Moderated Uranium-Aluminide Fuel Plates Reflected by Beryllium," INL/EXT-05-00780, September 2005; published in "International Handbook of Evaluated Criticality Safety Benchmark Experiments," NEA/NSC/DOC/(95)03/II, Volume II, HEU-MET-THERM-022, September 2005 Edition.

[11] G. L. Sharp, "ATRC SAR Upgrade Evaluation Guidelines and Accident Sequence Definitions," TRA-ATRC-1740, Rev. 1, April 2003.

[12] "Safety Analysis to Support KJRR-FAI Experiment Storage and Handling for Testing in the Advanced Test Reactor Critical (ATRC) Facility," TEV-2144, Rev 1, October 2014. 
[13] "Knovel Steam Tables," Knovel 2006, http://app.knovel.com/web/toc.v/cid:kpKST00001/viewerType:toc/root slug:knovelsteam-tables/url slug:knovel-steam-tables/?.

[14] R. T. McCracken, L. S. Loret, "Results of the ATR Critical Facility Core Reconfiguration and Requalification Testing and Post-Core Internals Changeout Operations," PG-T-94-006, June 1994.

[15] MP-11.8, "ATRC Outer Shim Reactivity Measurements," Rev. 4., January 13, 2009.

[16] McCracken, R. T., "Control Element Reactivities for the Advanced Test Reactor Critical Facility Safety Analysis Upgrade," TRA-ATR-1719, Rev. 1, January 3, 2002. 
ECAR-2705

Rev. 0
Physics Analysis to Support Advanced Test Reactor Critical

Facility Testing of the KJRR-FAI Experiment

\section{Attachment A - Calculated KJRR-FAl experiment heating}

\begin{tabular}{|c|c|c|c|c|}
\hline Plate & Node & $\begin{array}{c}\text { Total } \\
\text { MeV/source } \\
\text { particle }\end{array}$ & $\mathrm{MeV} / \mathrm{cc}$ & $\begin{array}{l}\text { Point To } \\
\text { Average }\end{array}$ \\
\hline \multirow{20}{*}{1} & 1 & 4.77E-03 & $5.03 \mathrm{E}-03$ & 0.86 \\
\hline & 2 & $4.63 \mathrm{E}-03$ & $4.88 \mathrm{E}-03$ & 0.83 \\
\hline & 3 & $5.14 \mathrm{E}-03$ & $5.42 \mathrm{E}-03$ & 0.92 \\
\hline & 4 & $5.58 \mathrm{E}-03$ & $5.88 \mathrm{E}-03$ & 1.00 \\
\hline & 5 & $5.89 \mathrm{E}-03$ & $6.20 \mathrm{E}-03$ & 1.06 \\
\hline & 6 & $6.15 \mathrm{E}-03$ & $6.48 \mathrm{E}-03$ & 1.10 \\
\hline & 7 & $6.35 \mathrm{E}-03$ & $6.69 \mathrm{E}-03$ & 1.14 \\
\hline & 8 & $6.47 \mathrm{E}-03$ & $6.82 \mathrm{E}-03$ & 1.16 \\
\hline & 9 & $6.60 \mathrm{E}-03$ & $6.96 \mathrm{E}-03$ & 1.19 \\
\hline & 10 & $6.67 \mathrm{E}-03$ & $7.03 \mathrm{E}-03$ & 1.20 \\
\hline & 11 & $6.66 \mathrm{E}-03$ & $7.02 \mathrm{E}-03$ & 1.20 \\
\hline & 12 & 6.64E-03 & $7.00 \mathrm{E}-03$ & 1.19 \\
\hline & 13 & $6.53 \mathrm{E}-03$ & $6.88 \mathrm{E}-03$ & 1.17 \\
\hline & 14 & $6.40 \mathrm{E}-03$ & $6.75 \mathrm{E}-03$ & 1.15 \\
\hline & 15 & $6.20 \mathrm{E}-03$ & $6.54 \mathrm{E}-03$ & 1.11 \\
\hline & 16 & $5.96 \mathrm{E}-03$ & $6.28 \mathrm{E}-03$ & 1.07 \\
\hline & 17 & $5.68 \mathrm{E}-03$ & $5.98 \mathrm{E}-03$ & 1.02 \\
\hline & 18 & $5.26 \mathrm{E}-03$ & $5.54 \mathrm{E}-03$ & 0.94 \\
\hline & 19 & $4.68 \mathrm{E}-03$ & $4.94 \mathrm{E}-03$ & 0.84 \\
\hline & 20 & 4.69E-03 & $4.95 \mathrm{E}-03$ & 0.84 \\
\hline \multirow{18}{*}{2} & 21 & $5.32 \mathrm{E}-03$ & $5.61 \mathrm{E}-03$ & 0.96 \\
\hline & 22 & $4.98 \mathrm{E}-03$ & $5.25 \mathrm{E}-03$ & 0.89 \\
\hline & 23 & 5.49E-03 & $5.79 \mathrm{E}-03$ & 0.99 \\
\hline & 24 & $5.92 \mathrm{E}-03$ & $6.24 \mathrm{E}-03$ & 1.06 \\
\hline & 25 & $6.24 \mathrm{E}-03$ & $6.58 \mathrm{E}-03$ & 1.12 \\
\hline & 26 & $6.53 \mathrm{E}-03$ & $6.89 \mathrm{E}-03$ & 1.17 \\
\hline & 27 & $6.73 \mathrm{E}-03$ & $7.10 \mathrm{E}-03$ & 1.21 \\
\hline & 28 & $6.93 \mathrm{E}-03$ & $7.31 \mathrm{E}-03$ & 1.25 \\
\hline & 29 & 6.99E-03 & $7.37 \mathrm{E}-03$ & 1.26 \\
\hline & 30 & 7.07E-03 & $7.45 \mathrm{E}-03$ & 1.27 \\
\hline & 31 & 7.09E-03 & 7.47E-03 & 1.27 \\
\hline & 32 & $7.05 E-03$ & $7.43 \mathrm{E}-03$ & 1.27 \\
\hline & 33 & $6.93 \mathrm{E}-03$ & $7.31 \mathrm{E}-03$ & 1.25 \\
\hline & 34 & $6.80 \mathrm{E}-03$ & $7.17 \mathrm{E}-03$ & 1.22 \\
\hline & 35 & $6.62 \mathrm{E}-03$ & $6.98 \mathrm{E}-03$ & 1.19 \\
\hline & 36 & $6.34 \mathrm{E}-03$ & $6.69 \mathrm{E}-03$ & 1.14 \\
\hline & 37 & $6.00 \mathrm{E}-03$ & $6.33 \mathrm{E}-03$ & 1.08 \\
\hline & 38 & $5.60 \mathrm{E}-03$ & $5.90 \mathrm{E}-03$ & 1.01 \\
\hline
\end{tabular}


ECAR-2705

Rev. 0
Physics Analysis to Support Advanced Test Reactor Critical Facility Testing of the KJRR-FAI Experiment

\begin{tabular}{|c|c|c|c|c|}
\hline Plate & Node & $\begin{array}{c}\text { Total } \\
\text { MeV/source } \\
\text { particle }\end{array}$ & $\mathrm{MeV} / \mathrm{cc}$ & $\begin{array}{l}\text { Point To } \\
\text { Average }\end{array}$ \\
\hline & 39 & $5.05 \mathrm{E}-03$ & $5.33 \mathrm{E}-03$ & 0.91 \\
\hline & 40 & $5.23 \mathrm{E}-03$ & $5.51 \mathrm{E}-03$ & 0.94 \\
\hline \multirow{20}{*}{3} & 41 & $5.11 \mathrm{E}-03$ & $5.38 \mathrm{E}-03$ & 0.92 \\
\hline & 42 & $4.62 \mathrm{E}-03$ & $4.87 E-03$ & 0.83 \\
\hline & 43 & $5.09 \mathrm{E}-03$ & $5.36 \mathrm{E}-03$ & 0.91 \\
\hline & 44 & $5.47 \mathrm{E}-03$ & $5.77 \mathrm{E}-03$ & 0.98 \\
\hline & 45 & $5.77 \mathrm{E}-03$ & $6.08 \mathrm{E}-03$ & 1.04 \\
\hline & 46 & $6.03 \mathrm{E}-03$ & $6.35 \mathrm{E}-03$ & 1.08 \\
\hline & 47 & $6.24 \mathrm{E}-03$ & $6.58 \mathrm{E}-03$ & 1.12 \\
\hline & 48 & $6.39 \mathrm{E}-03$ & $6.73 \mathrm{E}-03$ & 1.15 \\
\hline & 49 & $6.47 \mathrm{E}-03$ & $6.82 \mathrm{E}-03$ & 1.16 \\
\hline & 50 & $6.52 \mathrm{E}-03$ & $6.88 \mathrm{E}-03$ & 1.17 \\
\hline & 51 & $6.55 \mathrm{E}-03$ & $6.91 \mathrm{E}-03$ & 1.18 \\
\hline & 52 & $6.49 \mathrm{E}-03$ & $6.84 \mathrm{E}-03$ & 1.17 \\
\hline & 53 & $6.40 \mathrm{E}-03$ & $6.75 \mathrm{E}-03$ & 1.15 \\
\hline & 54 & $6.28 \mathrm{E}-03$ & $6.62 \mathrm{E}-03$ & 1.13 \\
\hline & 55 & $6.10 \mathrm{E}-03$ & $6.43 \mathrm{E}-03$ & 1.10 \\
\hline & 56 & $5.87 \mathrm{E}-03$ & $6.19 \mathrm{E}-03$ & 1.05 \\
\hline & 57 & $5.56 \mathrm{E}-03$ & $5.87 \mathrm{E}-03$ & 1.00 \\
\hline & 58 & 5.19E-03 & $5.47 \mathrm{E}-03$ & 0.93 \\
\hline & 59 & $4.72 \mathrm{E}-03$ & 4.97E-03 & 0.85 \\
\hline & 60 & 5.04E-03 & $5.31 \mathrm{E}-03$ & 0.91 \\
\hline \multirow{18}{*}{4} & 61 & $5.00 \mathrm{E}-03$ & $5.28 \mathrm{E}-03$ & 0.90 \\
\hline & 62 & 4.44E-03 & $4.68 \mathrm{E}-03$ & 0.80 \\
\hline & 63 & $4.84 \mathrm{E}-03$ & $5.11 \mathrm{E}-03$ & 0.87 \\
\hline & 64 & 5.19E-03 & $5.47 \mathrm{E}-03$ & 0.93 \\
\hline & 65 & $5.50 \mathrm{E}-03$ & $5.79 \mathrm{E}-03$ & 0.99 \\
\hline & 66 & $5.74 \mathrm{E}-03$ & $6.05 \mathrm{E}-03$ & 1.03 \\
\hline & 67 & 5.94E-03 & $6.26 \mathrm{E}-03$ & 1.07 \\
\hline & 68 & $6.08 \mathrm{E}-03$ & $6.41 \mathrm{E}-03$ & 1.09 \\
\hline & 69 & $6.16 \mathrm{E}-03$ & $6.49 \mathrm{E}-03$ & 1.11 \\
\hline & 70 & $6.21 \mathrm{E}-03$ & $6.54 \mathrm{E}-03$ & 1.12 \\
\hline & 71 & $6.24 \mathrm{E}-03$ & $6.58 \mathrm{E}-03$ & 1.12 \\
\hline & 72 & $6.18 \mathrm{E}-03$ & $6.52 \mathrm{E}-03$ & 1.11 \\
\hline & 73 & $6.12 \mathrm{E}-03$ & $6.45 \mathrm{E}-03$ & 1.10 \\
\hline & 74 & 5.99E-03 & $6.32 \mathrm{E}-03$ & 1.08 \\
\hline & 75 & $5.79 E-03$ & $6.10 \mathrm{E}-03$ & 1.04 \\
\hline & 76 & $5.60 \mathrm{E}-03$ & $5.91 \mathrm{E}-03$ & 1.01 \\
\hline & 77 & $5.32 \mathrm{E}-03$ & $5.61 \mathrm{E}-03$ & 0.96 \\
\hline & 78 & $4.96 \mathrm{E}-03$ & $5.22 \mathrm{E}-03$ & 0.89 \\
\hline
\end{tabular}


ECAR-2705

Rev. 0
Physics Analysis to Support Advanced Test Reactor Critical Facility Testing of the KJRR-FAI Experiment

\begin{tabular}{|c|c|c|c|c|}
\hline Plate & Node & $\begin{array}{c}\text { Total } \\
\text { MeV/source } \\
\text { particle }\end{array}$ & $\mathrm{MeV} / \mathrm{cc}$ & $\begin{array}{l}\text { Point To } \\
\text { Average }\end{array}$ \\
\hline & 79 & $4.55 \mathrm{E}-03$ & $4.79 E-03$ & 0.82 \\
\hline & 80 & $4.94 \mathrm{E}-03$ & $5.20 \mathrm{E}-03$ & 0.89 \\
\hline \multirow{20}{*}{5} & 81 & $4.99 \mathrm{E}-03$ & $5.26 \mathrm{E}-03$ & 0.90 \\
\hline & 82 & $4.31 \mathrm{E}-03$ & $4.55 \mathrm{E}-03$ & 0.78 \\
\hline & 83 & $4.72 \mathrm{E}-03$ & 4.97E-03 & 0.85 \\
\hline & 84 & $5.06 \mathrm{E}-03$ & $5.33 \mathrm{E}-03$ & 0.91 \\
\hline & 85 & $5.35 \mathrm{E}-03$ & $5.64 \mathrm{E}-03$ & 0.96 \\
\hline & 86 & 5.57E-03 & $5.87 \mathrm{E}-03$ & 1.00 \\
\hline & 87 & $5.76 \mathrm{E}-03$ & $6.07 E-03$ & 1.03 \\
\hline & 88 & $5.91 \mathrm{E}-03$ & $6.23 \mathrm{E}-03$ & 1.06 \\
\hline & 89 & $6.00 \mathrm{E}-03$ & $6.32 \mathrm{E}-03$ & 1.08 \\
\hline & 90 & $6.04 \mathrm{E}-03$ & $6.37 \mathrm{E}-03$ & 1.09 \\
\hline & 91 & $6.05 \mathrm{E}-03$ & $6.38 \mathrm{E}-03$ & 1.09 \\
\hline & 92 & $6.01 \mathrm{E}-03$ & $6.34 \mathrm{E}-03$ & 1.08 \\
\hline & 93 & $5.96 \mathrm{E}-03$ & $6.29 \mathrm{E}-03$ & 1.07 \\
\hline & 94 & $5.81 \mathrm{E}-03$ & $6.13 \mathrm{E}-03$ & 1.04 \\
\hline & 95 & $5.64 \mathrm{E}-03$ & $5.95 \mathrm{E}-03$ & 1.01 \\
\hline & 96 & $5.46 \mathrm{E}-03$ & $5.75 \mathrm{E}-03$ & 0.98 \\
\hline & 97 & $5.17 \mathrm{E}-03$ & $5.45 \mathrm{E}-03$ & 0.93 \\
\hline & 98 & $4.81 \mathrm{E}-03$ & $5.07 \mathrm{E}-03$ & 0.86 \\
\hline & 99 & $4.42 \mathrm{E}-03$ & $4.66 \mathrm{E}-03$ & 0.79 \\
\hline & 100 & $4.91 \mathrm{E}-03$ & $5.18 \mathrm{E}-03$ & 0.88 \\
\hline \multirow{18}{*}{6} & 101 & $4.99 \mathrm{E}-03$ & $5.26 \mathrm{E}-03$ & 0.90 \\
\hline & 102 & $4.26 \mathrm{E}-03$ & 4.49E-03 & 0.77 \\
\hline & 103 & $4.63 \mathrm{E}-03$ & $4.89 \mathrm{E}-03$ & 0.83 \\
\hline & 104 & 4.97E-03 & $5.24 \mathrm{E}-03$ & 0.89 \\
\hline & 105 & $5.25 \mathrm{E}-03$ & $5.54 \mathrm{E}-03$ & 0.94 \\
\hline & 106 & $5.48 \mathrm{E}-03$ & $5.78 \mathrm{E}-03$ & 0.99 \\
\hline & 107 & 5.67E-03 & $5.98 \mathrm{E}-03$ & 1.02 \\
\hline & 108 & $5.80 \mathrm{E}-03$ & $6.12 \mathrm{E}-03$ & 1.04 \\
\hline & 109 & $5.90 \mathrm{E}-03$ & $6.22 \mathrm{E}-03$ & 1.06 \\
\hline & 110 & $5.96 \mathrm{E}-03$ & $6.28 \mathrm{E}-03$ & 1.07 \\
\hline & 111 & $5.96 \mathrm{E}-03$ & $6.28 \mathrm{E}-03$ & 1.07 \\
\hline & 112 & 5.91E-03 & $6.23 \mathrm{E}-03$ & 1.06 \\
\hline & 113 & $5.85 \mathrm{E}-03$ & $6.17 \mathrm{E}-03$ & 1.05 \\
\hline & 114 & $5.73 \mathrm{E}-03$ & $6.04 \mathrm{E}-03$ & 1.03 \\
\hline & 115 & $5.55 \mathrm{E}-03$ & $5.85 \mathrm{E}-03$ & 1.00 \\
\hline & 116 & $5.36 \mathrm{E}-03$ & $5.65 \mathrm{E}-03$ & 0.96 \\
\hline & 117 & $5.07 \mathrm{E}-03$ & $5.35 \mathrm{E}-03$ & 0.91 \\
\hline & 118 & $4.76 \mathrm{E}-03$ & 5.02E-03 & 0.86 \\
\hline
\end{tabular}


ECAR-2705

Rev. 0
Physics Analysis to Support Advanced Test Reactor Critical Facility Testing of the KJRR-FAI Experiment

\begin{tabular}{|c|c|c|c|c|}
\hline Plate & Node & $\begin{array}{c}\text { Total } \\
\text { MeV/source } \\
\text { particle }\end{array}$ & $\mathrm{MeV} / \mathrm{cc}$ & $\begin{array}{l}\text { Point To } \\
\text { Average }\end{array}$ \\
\hline & 119 & $4.36 \mathrm{E}-03$ & $4.59 \mathrm{E}-03$ & 0.78 \\
\hline & 120 & $4.90 \mathrm{E}-03$ & $5.17 \mathrm{E}-03$ & 0.88 \\
\hline \multirow{20}{*}{7} & 121 & $5.00 \mathrm{E}-03$ & $5.27 \mathrm{E}-03$ & 0.90 \\
\hline & 122 & $4.24 \mathrm{E}-03$ & 4.47E-03 & 0.76 \\
\hline & 123 & $4.62 \mathrm{E}-03$ & 4.87E-03 & 0.83 \\
\hline & 124 & 4.94E-03 & $5.21 \mathrm{E}-03$ & 0.89 \\
\hline & 125 & $5.22 \mathrm{E}-03$ & $5.50 \mathrm{E}-03$ & 0.94 \\
\hline & 126 & 5.44E-03 & $5.74 \mathrm{E}-03$ & 0.98 \\
\hline & 127 & $5.61 \mathrm{E}-03$ & $5.91 \mathrm{E}-03$ & 1.01 \\
\hline & 128 & $5.76 \mathrm{E}-03$ & $6.07 \mathrm{E}-03$ & 1.03 \\
\hline & 129 & $5.85 \mathrm{E}-03$ & $6.17 \mathrm{E}-03$ & 1.05 \\
\hline & 130 & 5.89E-03 & $6.21 \mathrm{E}-03$ & 1.06 \\
\hline & 131 & $5.90 \mathrm{E}-03$ & $6.22 \mathrm{E}-03$ & 1.06 \\
\hline & 132 & $5.85 \mathrm{E}-03$ & $6.17 \mathrm{E}-03$ & 1.05 \\
\hline & 133 & $5.80 \mathrm{E}-03$ & $6.11 \mathrm{E}-03$ & 1.04 \\
\hline & 134 & 5.67E-03 & 5.97E-03 & 1.02 \\
\hline & 135 & $5.48 \mathrm{E}-03$ & $5.78 \mathrm{E}-03$ & 0.98 \\
\hline & 136 & $5.30 \mathrm{E}-03$ & $5.59 \mathrm{E}-03$ & 0.95 \\
\hline & 137 & $5.04 \mathrm{E}-03$ & $5.31 \mathrm{E}-03$ & 0.91 \\
\hline & 138 & $4.73 E-03$ & 4.99E-03 & 0.85 \\
\hline & 139 & $4.32 \mathrm{E}-03$ & $4.56 \mathrm{E}-03$ & 0.78 \\
\hline & 140 & $4.95 \mathrm{E}-03$ & $5.22 \mathrm{E}-03$ & 0.89 \\
\hline \multirow{18}{*}{8} & 141 & $5.02 \mathrm{E}-03$ & $5.29 \mathrm{E}-03$ & 0.90 \\
\hline & 142 & $4.22 \mathrm{E}-03$ & $4.45 \mathrm{E}-03$ & 0.76 \\
\hline & 143 & 4.60E-03 & $4.85 \mathrm{E}-03$ & 0.83 \\
\hline & 144 & $4.91 \mathrm{E}-03$ & $5.18 \mathrm{E}-03$ & 0.88 \\
\hline & 145 & $5.18 \mathrm{E}-03$ & $5.46 \mathrm{E}-03$ & 0.93 \\
\hline & 146 & $5.43 \mathrm{E}-03$ & $5.73 \mathrm{E}-03$ & 0.98 \\
\hline & 147 & $5.58 \mathrm{E}-03$ & $5.88 \mathrm{E}-03$ & 1.00 \\
\hline & 148 & $5.73 E-03$ & $6.04 \mathrm{E}-03$ & 1.03 \\
\hline & 149 & $5.82 \mathrm{E}-03$ & $6.14 \mathrm{E}-03$ & 1.05 \\
\hline & 150 & 5.86E-03 & $6.18 \mathrm{E}-03$ & 1.05 \\
\hline & 151 & 5.87E-03 & $6.19 \mathrm{E}-03$ & 1.05 \\
\hline & 152 & 5.84E-03 & $6.16 \mathrm{E}-03$ & 1.05 \\
\hline & 153 & $5.75 \mathrm{E}-03$ & $6.06 \mathrm{E}-03$ & 1.03 \\
\hline & 154 & 5.64E-03 & $5.95 \mathrm{E}-03$ & 1.01 \\
\hline & 155 & $5.47 \mathrm{E}-03$ & $5.76 \mathrm{E}-03$ & 0.98 \\
\hline & 156 & $5.25 \mathrm{E}-03$ & $5.53 \mathrm{E}-03$ & 0.94 \\
\hline & 157 & 5.00E-03 & $5.28 \mathrm{E}-03$ & 0.90 \\
\hline & 158 & $4.69 \mathrm{E}-03$ & $4.95 \mathrm{E}-03$ & 0.84 \\
\hline
\end{tabular}


ECAR-2705

Rev. 0
Physics Analysis to Support Advanced Test Reactor Critical Facility Testing of the KJRR-FAI Experiment

\begin{tabular}{|c|c|c|c|c|}
\hline Plate & Node & $\begin{array}{c}\text { Total } \\
\text { MeV/source } \\
\text { particle }\end{array}$ & $\mathrm{MeV} / \mathrm{cc}$ & $\begin{array}{l}\text { Point To } \\
\text { Average }\end{array}$ \\
\hline & 159 & $4.31 \mathrm{E}-03$ & $4.54 \mathrm{E}-03$ & 0.77 \\
\hline & 160 & $4.96 \mathrm{E}-03$ & $5.23 \mathrm{E}-03$ & 0.89 \\
\hline \multirow{20}{*}{9} & 161 & $5.04 \mathrm{E}-03$ & $5.31 \mathrm{E}-03$ & 0.91 \\
\hline & 162 & $4.23 \mathrm{E}-03$ & 4.46E-03 & 0.76 \\
\hline & 163 & 4.57E-03 & $4.82 \mathrm{E}-03$ & 0.82 \\
\hline & 164 & 4.90E-03 & $5.17 \mathrm{E}-03$ & 0.88 \\
\hline & 165 & $5.19 \mathrm{E}-03$ & $5.47 \mathrm{E}-03$ & 0.93 \\
\hline & 166 & 5.39E-03 & $5.68 \mathrm{E}-03$ & 0.97 \\
\hline & 167 & $5.58 \mathrm{E}-03$ & $5.88 \mathrm{E}-03$ & 1.00 \\
\hline & 168 & $5.72 \mathrm{E}-03$ & $6.03 \mathrm{E}-03$ & 1.03 \\
\hline & 169 & $5.81 \mathrm{E}-03$ & $6.12 \mathrm{E}-03$ & 1.04 \\
\hline & 170 & 5.84E-03 & $6.15 \mathrm{E}-03$ & 1.05 \\
\hline & 171 & $5.86 \mathrm{E}-03$ & $6.18 \mathrm{E}-03$ & 1.05 \\
\hline & 172 & 5.82E-03 & $6.14 \mathrm{E}-03$ & 1.05 \\
\hline & 173 & $5.74 \mathrm{E}-03$ & $6.05 \mathrm{E}-03$ & 1.03 \\
\hline & 174 & $5.62 \mathrm{E}-03$ & 5.93E-03 & 1.01 \\
\hline & 175 & $5.47 \mathrm{E}-03$ & $5.77 \mathrm{E}-03$ & 0.98 \\
\hline & 176 & $5.26 \mathrm{E}-03$ & $5.54 \mathrm{E}-03$ & 0.94 \\
\hline & 177 & $4.99 \mathrm{E}-03$ & $5.26 \mathrm{E}-03$ & 0.90 \\
\hline & 178 & 4.69E-03 & $4.94 \mathrm{E}-03$ & 0.84 \\
\hline & 179 & 4.30E-03 & 4.54E-03 & 0.77 \\
\hline & 180 & 4.99E-03 & $5.26 \mathrm{E}-03$ & 0.90 \\
\hline \multirow{18}{*}{10} & 181 & 5.07E-03 & $5.34 \mathrm{E}-03$ & 0.91 \\
\hline & 182 & $4.21 \mathrm{E}-03$ & 4.44E-03 & 0.76 \\
\hline & 183 & 4.57E-03 & $4.82 \mathrm{E}-03$ & 0.82 \\
\hline & 184 & $4.92 \mathrm{E}-03$ & $5.18 \mathrm{E}-03$ & 0.88 \\
\hline & 185 & 5.19E-03 & 5.47E-03 & 0.93 \\
\hline & 186 & 5.39E-03 & $5.68 \mathrm{E}-03$ & 0.97 \\
\hline & 187 & 5.57E-03 & 5.87E-03 & 1.00 \\
\hline & 188 & $5.74 \mathrm{E}-03$ & $6.05 \mathrm{E}-03$ & 1.03 \\
\hline & 189 & $5.81 \mathrm{E}-03$ & $6.13 \mathrm{E}-03$ & 1.04 \\
\hline & 190 & 5.84E-03 & $6.15 \mathrm{E}-03$ & 1.05 \\
\hline & 191 & $5.85 \mathrm{E}-03$ & $6.17 E-03$ & 1.05 \\
\hline & 192 & 5.82E-03 & $6.14 \mathrm{E}-03$ & 1.05 \\
\hline & 193 & $5.76 \mathrm{E}-03$ & $6.07 \mathrm{E}-03$ & 1.04 \\
\hline & 194 & 5.62E-03 & $5.92 \mathrm{E}-03$ & 1.01 \\
\hline & 195 & $5.47 \mathrm{E}-03$ & $5.77 \mathrm{E}-03$ & 0.98 \\
\hline & 196 & $5.24 \mathrm{E}-03$ & $5.53 \mathrm{E}-03$ & 0.94 \\
\hline & 197 & 5.00E-03 & $5.27 \mathrm{E}-03$ & 0.90 \\
\hline & 198 & $4.68 \mathrm{E}-03$ & $4.93 \mathrm{E}-03$ & 0.84 \\
\hline
\end{tabular}


ECAR-2705

Rev. 0
Physics Analysis to Support Advanced Test Reactor Critical Facility Testing of the KJRR-FAI Experiment

\begin{tabular}{|c|c|c|c|c|}
\hline Plate & Node & $\begin{array}{c}\text { Total } \\
\text { MeV/source } \\
\text { particle }\end{array}$ & $\mathrm{MeV} / \mathrm{cc}$ & $\begin{array}{l}\text { Point To } \\
\text { Average }\end{array}$ \\
\hline & 199 & $4.30 \mathrm{E}-03$ & $4.54 \mathrm{E}-03$ & 0.77 \\
\hline & 200 & $4.97 \mathrm{E}-03$ & $5.24 \mathrm{E}-03$ & 0.89 \\
\hline \multirow{20}{*}{11} & 201 & $5.08 \mathrm{E}-03$ & $5.35 \mathrm{E}-03$ & 0.91 \\
\hline & 202 & $4.22 \mathrm{E}-03$ & 4.45E-03 & 0.76 \\
\hline & 203 & $4.58 \mathrm{E}-03$ & 4.83E-03 & 0.82 \\
\hline & 204 & 4.94E-03 & $5.21 \mathrm{E}-03$ & 0.89 \\
\hline & 205 & $5.20 \mathrm{E}-03$ & $5.48 \mathrm{E}-03$ & 0.93 \\
\hline & 206 & $5.40 \mathrm{E}-03$ & $5.70 \mathrm{E}-03$ & 0.97 \\
\hline & 207 & $5.59 \mathrm{E}-03$ & $5.89 \mathrm{E}-03$ & 1.00 \\
\hline & 208 & $5.72 \mathrm{E}-03$ & $6.03 \mathrm{E}-03$ & 1.03 \\
\hline & 209 & $5.82 \mathrm{E}-03$ & $6.13 \mathrm{E}-03$ & 1.05 \\
\hline & 210 & $5.85 \mathrm{E}-03$ & $6.17 \mathrm{E}-03$ & 1.05 \\
\hline & 211 & $5.85 \mathrm{E}-03$ & $6.17 E-03$ & 1.05 \\
\hline & 212 & 5.83E-03 & $6.15 \mathrm{E}-03$ & 1.05 \\
\hline & 213 & $5.76 \mathrm{E}-03$ & $6.07 \mathrm{E}-03$ & 1.04 \\
\hline & 214 & $5.65 \mathrm{E}-03$ & $5.95 \mathrm{E}-03$ & 1.01 \\
\hline & 215 & $5.46 \mathrm{E}-03$ & $5.76 \mathrm{E}-03$ & 0.98 \\
\hline & 216 & $5.28 \mathrm{E}-03$ & 5.57E-03 & 0.95 \\
\hline & 217 & $5.00 \mathrm{E}-03$ & $5.27 \mathrm{E}-03$ & 0.90 \\
\hline & 218 & $4.68 \mathrm{E}-03$ & $4.94 \mathrm{E}-03$ & 0.84 \\
\hline & 219 & $4.32 \mathrm{E}-03$ & $4.56 \mathrm{E}-03$ & 0.78 \\
\hline & 220 & 4.99E-03 & $5.26 \mathrm{E}-03$ & 0.90 \\
\hline \multirow{18}{*}{12} & 221 & 5.07E-03 & $5.35 \mathrm{E}-03$ & 0.91 \\
\hline & 222 & $4.23 \mathrm{E}-03$ & $4.46 \mathrm{E}-03$ & 0.76 \\
\hline & 223 & $4.61 \mathrm{E}-03$ & $4.86 \mathrm{E}-03$ & 0.83 \\
\hline & 224 & $4.93 \mathrm{E}-03$ & $5.20 \mathrm{E}-03$ & 0.89 \\
\hline & 225 & 5.19E-03 & 5.47E-03 & 0.93 \\
\hline & 226 & $5.42 \mathrm{E}-03$ & $5.71 \mathrm{E}-03$ & 0.97 \\
\hline & 227 & $5.60 \mathrm{E}-03$ & $5.90 \mathrm{E}-03$ & 1.01 \\
\hline & 228 & $5.76 \mathrm{E}-03$ & $6.07 \mathrm{E}-03$ & 1.03 \\
\hline & 229 & $5.84 \mathrm{E}-03$ & $6.16 \mathrm{E}-03$ & 1.05 \\
\hline & 230 & 5.85E-03 & $6.17 \mathrm{E}-03$ & 1.05 \\
\hline & 231 & $5.89 \mathrm{E}-03$ & $6.21 \mathrm{E}-03$ & 1.06 \\
\hline & 232 & 5.83E-03 & $6.15 \mathrm{E}-03$ & 1.05 \\
\hline & 233 & $5.77 \mathrm{E}-03$ & $6.08 \mathrm{E}-03$ & 1.04 \\
\hline & 234 & 5.67E-03 & $5.98 \mathrm{E}-03$ & 1.02 \\
\hline & 235 & $5.48 \mathrm{E}-03$ & $5.78 \mathrm{E}-03$ & 0.98 \\
\hline & 236 & $5.28 \mathrm{E}-03$ & $5.57 \mathrm{E}-03$ & 0.95 \\
\hline & 237 & 5.02E-03 & $5.30 \mathrm{E}-03$ & 0.90 \\
\hline & 238 & $4.69 \mathrm{E}-03$ & $4.95 \mathrm{E}-03$ & 0.84 \\
\hline
\end{tabular}


ECAR-2705

Rev. 0
Physics Analysis to Support Advanced Test Reactor Critical Facility Testing of the KJRR-FAI Experiment

\begin{tabular}{|c|c|c|c|c|}
\hline Plate & Node & $\begin{array}{c}\text { Total } \\
\text { MeV/source } \\
\text { particle }\end{array}$ & $\mathrm{MeV} / \mathrm{cc}$ & $\begin{array}{l}\text { Point To } \\
\text { Average }\end{array}$ \\
\hline & 239 & $4.32 \mathrm{E}-03$ & 4.56E-03 & 0.78 \\
\hline & 240 & $5.02 \mathrm{E}-03$ & $5.29 \mathrm{E}-03$ & 0.90 \\
\hline \multirow{20}{*}{13} & 241 & $5.09 \mathrm{E}-03$ & $5.36 \mathrm{E}-03$ & 0.91 \\
\hline & 242 & $4.25 \mathrm{E}-03$ & $4.48 \mathrm{E}-03$ & 0.76 \\
\hline & 243 & $4.62 \mathrm{E}-03$ & 4.87E-03 & 0.83 \\
\hline & 244 & 4.96E-03 & $5.22 \mathrm{E}-03$ & 0.89 \\
\hline & 245 & $5.23 \mathrm{E}-03$ & $5.51 \mathrm{E}-03$ & 0.94 \\
\hline & 246 & $5.43 \mathrm{E}-03$ & $5.72 \mathrm{E}-03$ & 0.98 \\
\hline & 247 & $5.64 \mathrm{E}-03$ & $5.94 \mathrm{E}-03$ & 1.01 \\
\hline & 248 & $5.77 \mathrm{E}-03$ & $6.08 \mathrm{E}-03$ & 1.04 \\
\hline & 249 & $5.86 \mathrm{E}-03$ & $6.17 \mathrm{E}-03$ & 1.05 \\
\hline & 250 & 5.89E-03 & $6.21 \mathrm{E}-03$ & 1.06 \\
\hline & 251 & $5.93 \mathrm{E}-03$ & $6.25 \mathrm{E}-03$ & 1.06 \\
\hline & 252 & $5.86 \mathrm{E}-03$ & $6.18 \mathrm{E}-03$ & 1.05 \\
\hline & 253 & $5.79 E-03$ & $6.11 \mathrm{E}-03$ & 1.04 \\
\hline & 254 & 5.66E-03 & 5.97E-03 & 1.02 \\
\hline & 255 & $5.49 \mathrm{E}-03$ & $5.78 \mathrm{E}-03$ & 0.99 \\
\hline & 256 & $5.27 \mathrm{E}-03$ & $5.56 \mathrm{E}-03$ & 0.95 \\
\hline & 257 & $5.03 \mathrm{E}-03$ & $5.30 \mathrm{E}-03$ & 0.90 \\
\hline & 258 & $4.72 \mathrm{E}-03$ & $4.98 \mathrm{E}-03$ & 0.85 \\
\hline & 259 & $4.36 \mathrm{E}-03$ & 4.60E-03 & 0.78 \\
\hline & 260 & 5.01E-03 & $5.28 \mathrm{E}-03$ & 0.90 \\
\hline \multirow{18}{*}{14} & 261 & 5.07E-03 & $5.35 \mathrm{E}-03$ & 0.91 \\
\hline & 262 & $4.28 \mathrm{E}-03$ & $4.51 \mathrm{E}-03$ & 0.77 \\
\hline & 263 & $4.64 \mathrm{E}-03$ & 4.89E-03 & 0.83 \\
\hline & 264 & 4.99E-03 & $5.26 \mathrm{E}-03$ & 0.90 \\
\hline & 265 & $5.26 \mathrm{E}-03$ & $5.54 \mathrm{E}-03$ & 0.95 \\
\hline & 266 & $5.48 \mathrm{E}-03$ & $5.78 \mathrm{E}-03$ & 0.98 \\
\hline & 267 & 5.64E-03 & $5.94 \mathrm{E}-03$ & 1.01 \\
\hline & 268 & $5.80 \mathrm{E}-03$ & $6.11 \mathrm{E}-03$ & 1.04 \\
\hline & 269 & 5.89E-03 & $6.21 \mathrm{E}-03$ & 1.06 \\
\hline & 270 & 5.93E-03 & $6.25 \mathrm{E}-03$ & 1.07 \\
\hline & 271 & 5.94E-03 & $6.26 \mathrm{E}-03$ & 1.07 \\
\hline & 272 & $5.88 \mathrm{E}-03$ & $6.20 \mathrm{E}-03$ & 1.06 \\
\hline & 273 & $5.83 \mathrm{E}-03$ & $6.14 \mathrm{E}-03$ & 1.05 \\
\hline & 274 & 5.69E-03 & $6.00 \mathrm{E}-03$ & 1.02 \\
\hline & 275 & 5.54E-03 & $5.84 \mathrm{E}-03$ & 1.00 \\
\hline & 276 & $5.32 \mathrm{E}-03$ & $5.61 \mathrm{E}-03$ & 0.96 \\
\hline & 277 & $5.07 \mathrm{E}-03$ & $5.34 \mathrm{E}-03$ & 0.91 \\
\hline & 278 & $4.74 \mathrm{E}-03$ & $5.00 \mathrm{E}-03$ & 0.85 \\
\hline
\end{tabular}


ECAR-2705

Rev. 0
Physics Analysis to Support Advanced Test Reactor Critical Facility Testing of the KJRR-FAI Experiment

\begin{tabular}{|c|c|c|c|c|}
\hline Plate & Node & $\begin{array}{c}\text { Total } \\
\text { MeV/source } \\
\text { particle }\end{array}$ & $\mathrm{MeV} / \mathrm{cc}$ & $\begin{array}{l}\text { Point To } \\
\text { Average }\end{array}$ \\
\hline & 279 & $4.38 \mathrm{E}-03$ & $4.62 \mathrm{E}-03$ & 0.79 \\
\hline & 280 & $5.04 \mathrm{E}-03$ & $5.31 \mathrm{E}-03$ & 0.91 \\
\hline \multirow{20}{*}{15} & 281 & $5.10 \mathrm{E}-03$ & 5.37E-03 & 0.92 \\
\hline & 282 & $4.32 \mathrm{E}-03$ & $4.56 \mathrm{E}-03$ & 0.78 \\
\hline & 283 & 4.69E-03 & 4.95E-03 & 0.84 \\
\hline & 284 & $5.02 \mathrm{E}-03$ & $5.29 \mathrm{E}-03$ & 0.90 \\
\hline & 285 & $5.30 \mathrm{E}-03$ & $5.58 \mathrm{E}-03$ & 0.95 \\
\hline & 286 & $5.50 \mathrm{E}-03$ & $5.80 \mathrm{E}-03$ & 0.99 \\
\hline & 287 & $5.68 \mathrm{E}-03$ & $5.99 \mathrm{E}-03$ & 1.02 \\
\hline & 288 & $5.84 \mathrm{E}-03$ & $6.16 \mathrm{E}-03$ & 1.05 \\
\hline & 289 & $5.92 \mathrm{E}-03$ & $6.24 \mathrm{E}-03$ & 1.06 \\
\hline & 290 & $5.98 \mathrm{E}-03$ & $6.30 \mathrm{E}-03$ & 1.07 \\
\hline & 291 & $5.98 \mathrm{E}-03$ & $6.30 \mathrm{E}-03$ & 1.07 \\
\hline & 292 & 5.93E-03 & $6.25 \mathrm{E}-03$ & 1.07 \\
\hline & 293 & $5.86 \mathrm{E}-03$ & $6.18 \mathrm{E}-03$ & 1.05 \\
\hline & 294 & $5.74 \mathrm{E}-03$ & $6.05 \mathrm{E}-03$ & 1.03 \\
\hline & 295 & $5.57 \mathrm{E}-03$ & $5.87 \mathrm{E}-03$ & 1.00 \\
\hline & 296 & 5.39E-03 & $5.68 \mathrm{E}-03$ & 0.97 \\
\hline & 297 & $5.10 \mathrm{E}-03$ & $5.38 \mathrm{E}-03$ & 0.92 \\
\hline & 298 & $4.78 \mathrm{E}-03$ & $5.04 \mathrm{E}-03$ & 0.86 \\
\hline & 299 & $4.40 \mathrm{E}-03$ & 4.63E-03 & 0.79 \\
\hline & 300 & $5.02 \mathrm{E}-03$ & $5.29 \mathrm{E}-03$ & 0.90 \\
\hline \multirow{18}{*}{16} & 301 & $5.12 \mathrm{E}-03$ & $5.40 \mathrm{E}-03$ & 0.92 \\
\hline & 302 & $4.38 \mathrm{E}-03$ & $4.62 \mathrm{E}-03$ & 0.79 \\
\hline & 303 & $4.76 \mathrm{E}-03$ & $5.02 \mathrm{E}-03$ & 0.86 \\
\hline & 304 & $5.10 \mathrm{E}-03$ & $5.38 \mathrm{E}-03$ & 0.92 \\
\hline & 305 & $5.35 \mathrm{E}-03$ & $5.64 \mathrm{E}-03$ & 0.96 \\
\hline & 306 & 5.57E-03 & $5.87 \mathrm{E}-03$ & 1.00 \\
\hline & 307 & $5.76 \mathrm{E}-03$ & 6.07E-03 & 1.03 \\
\hline & 308 & 5.92E-03 & $6.24 \mathrm{E}-03$ & 1.06 \\
\hline & 309 & $5.99 \mathrm{E}-03$ & $6.31 \mathrm{E}-03$ & 1.08 \\
\hline & 310 & $6.05 E-03$ & $6.38 \mathrm{E}-03$ & 1.09 \\
\hline & 311 & $6.06 \mathrm{E}-03$ & $6.39 \mathrm{E}-03$ & 1.09 \\
\hline & 312 & $6.01 \mathrm{E}-03$ & $6.34 \mathrm{E}-03$ & 1.08 \\
\hline & 313 & $5.96 \mathrm{E}-03$ & $6.28 \mathrm{E}-03$ & 1.07 \\
\hline & 314 & 5.81E-03 & $6.13 \mathrm{E}-03$ & 1.04 \\
\hline & 315 & 5.67E-03 & $5.98 \mathrm{E}-03$ & 1.02 \\
\hline & 316 & 5.44E-03 & $5.74 \mathrm{E}-03$ & 0.98 \\
\hline & 317 & $5.18 \mathrm{E}-03$ & $5.46 \mathrm{E}-03$ & 0.93 \\
\hline & 318 & $4.84 \mathrm{E}-03$ & $5.10 \mathrm{E}-03$ & 0.87 \\
\hline
\end{tabular}


ECAR-2705

Rev. 0
Physics Analysis to Support Advanced Test Reactor Critical Facility Testing of the KJRR-FAI Experiment

\begin{tabular}{|c|c|c|c|c|}
\hline Plate & Node & $\begin{array}{c}\text { Total } \\
\text { MeV/source } \\
\text { particle }\end{array}$ & $\mathrm{MeV} / \mathrm{cc}$ & $\begin{array}{l}\text { Point To } \\
\text { Average }\end{array}$ \\
\hline & 319 & $4.47 \mathrm{E}-03$ & $4.71 \mathrm{E}-03$ & 0.80 \\
\hline & 320 & $5.06 \mathrm{E}-03$ & $5.33 \mathrm{E}-03$ & 0.91 \\
\hline \multirow{20}{*}{17} & 321 & $5.14 \mathrm{E}-03$ & $5.42 \mathrm{E}-03$ & 0.92 \\
\hline & 322 & $4.46 \mathrm{E}-03$ & 4.70E-03 & 0.80 \\
\hline & 323 & 4.83E-03 & 5.09E-03 & 0.87 \\
\hline & 324 & 5.19E-03 & $5.48 \mathrm{E}-03$ & 0.93 \\
\hline & 325 & $5.48 \mathrm{E}-03$ & $5.78 \mathrm{E}-03$ & 0.98 \\
\hline & 326 & $5.71 \mathrm{E}-03$ & $6.02 \mathrm{E}-03$ & 1.03 \\
\hline & 327 & $5.91 \mathrm{E}-03$ & $6.23 \mathrm{E}-03$ & 1.06 \\
\hline & 328 & $6.01 \mathrm{E}-03$ & $6.34 \mathrm{E}-03$ & 1.08 \\
\hline & 329 & $6.14 \mathrm{E}-03$ & $6.47 \mathrm{E}-03$ & 1.10 \\
\hline & 330 & $6.17 \mathrm{E}-03$ & $6.51 \mathrm{E}-03$ & 1.11 \\
\hline & 331 & $6.17 \mathrm{E}-03$ & $6.51 \mathrm{E}-03$ & 1.11 \\
\hline & 332 & $6.14 \mathrm{E}-03$ & $6.47 \mathrm{E}-03$ & 1.10 \\
\hline & 333 & $6.08 \mathrm{E}-03$ & $6.41 \mathrm{E}-03$ & 1.09 \\
\hline & 334 & 5.95E-03 & $6.28 \mathrm{E}-03$ & 1.07 \\
\hline & 335 & $5.80 \mathrm{E}-03$ & $6.11 \mathrm{E}-03$ & 1.04 \\
\hline & 336 & 5.53E-03 & $5.83 \mathrm{E}-03$ & 0.99 \\
\hline & 337 & $5.29 \mathrm{E}-03$ & $5.58 \mathrm{E}-03$ & 0.95 \\
\hline & 338 & 4.97E-03 & $5.24 \mathrm{E}-03$ & 0.89 \\
\hline & 339 & $4.54 \mathrm{E}-03$ & 4.79E-03 & 0.82 \\
\hline & 340 & $5.08 \mathrm{E}-03$ & $5.36 \mathrm{E}-03$ & 0.91 \\
\hline \multirow{18}{*}{18} & 341 & $5.18 \mathrm{E}-03$ & $5.46 \mathrm{E}-03$ & 0.93 \\
\hline & 342 & 4.60E-03 & $4.85 \mathrm{E}-03$ & 0.83 \\
\hline & 343 & 5.03E-03 & $5.30 \mathrm{E}-03$ & 0.90 \\
\hline & 344 & $5.37 \mathrm{E}-03$ & $5.66 \mathrm{E}-03$ & 0.97 \\
\hline & 345 & $5.68 \mathrm{E}-03$ & 5.99E-03 & 1.02 \\
\hline & 346 & $5.88 \mathrm{E}-03$ & $6.20 \mathrm{E}-03$ & 1.06 \\
\hline & 347 & $6.09 \mathrm{E}-03$ & $6.41 \mathrm{E}-03$ & 1.09 \\
\hline & 348 & $6.24 \mathrm{E}-03$ & $6.58 \mathrm{E}-03$ & 1.12 \\
\hline & 349 & $6.33 \mathrm{E}-03$ & $6.67 \mathrm{E}-03$ & 1.14 \\
\hline & 350 & $6.38 \mathrm{E}-03$ & $6.72 \mathrm{E}-03$ & 1.15 \\
\hline & 351 & 6.39E-03 & $6.74 \mathrm{E}-03$ & 1.15 \\
\hline & 352 & $6.37 \mathrm{E}-03$ & $6.71 \mathrm{E}-03$ & 1.14 \\
\hline & 353 & $6.26 \mathrm{E}-03$ & $6.60 \mathrm{E}-03$ & 1.13 \\
\hline & 354 & $6.14 \mathrm{E}-03$ & $6.47 \mathrm{E}-03$ & 1.10 \\
\hline & 355 & 5.97E-03 & $6.29 \mathrm{E}-03$ & 1.07 \\
\hline & 356 & $5.74 \mathrm{E}-03$ & $6.06 \mathrm{E}-03$ & 1.03 \\
\hline & 357 & 5.46E-03 & $5.76 \mathrm{E}-03$ & 0.98 \\
\hline & 358 & $5.12 \mathrm{E}-03$ & $5.39 \mathrm{E}-03$ & 0.92 \\
\hline
\end{tabular}


ECAR-2705

Rev. 0
Physics Analysis to Support Advanced Test Reactor Critical Facility Testing of the KJRR-FAI Experiment

\begin{tabular}{|c|c|c|c|c|}
\hline Plate & Node & $\begin{array}{c}\text { Total } \\
\text { MeV/source } \\
\text { particle }\end{array}$ & $\mathrm{MeV} / \mathrm{cc}$ & $\begin{array}{l}\text { Point To } \\
\text { Average }\end{array}$ \\
\hline & 359 & 4.67E-03 & $4.92 \mathrm{E}-03$ & 0.84 \\
\hline & 360 & $5.13 \mathrm{E}-03$ & $5.41 \mathrm{E}-03$ & 0.92 \\
\hline \multirow{20}{*}{19} & 361 & $5.30 \mathrm{E}-03$ & $5.59 \mathrm{E}-03$ & 0.95 \\
\hline & 362 & $4.82 \mathrm{E}-03$ & $5.08 \mathrm{E}-03$ & 0.87 \\
\hline & 363 & $5.27 \mathrm{E}-03$ & $5.55 \mathrm{E}-03$ & 0.95 \\
\hline & 364 & 5.67E-03 & 5.97E-03 & 1.02 \\
\hline & 365 & $5.96 \mathrm{E}-03$ & $6.28 \mathrm{E}-03$ & 1.07 \\
\hline & 366 & $6.20 \mathrm{E}-03$ & $6.54 \mathrm{E}-03$ & 1.11 \\
\hline & 367 & $6.40 \mathrm{E}-03$ & $6.75 \mathrm{E}-03$ & 1.15 \\
\hline & 368 & $6.55 \mathrm{E}-03$ & $6.90 \mathrm{E}-03$ & 1.18 \\
\hline & 369 & $6.66 \mathrm{E}-03$ & $7.02 \mathrm{E}-03$ & 1.20 \\
\hline & 370 & $6.72 \mathrm{E}-03$ & $7.08 \mathrm{E}-03$ & 1.21 \\
\hline & 371 & $6.74 \mathrm{E}-03$ & $7.10 \mathrm{E}-03$ & 1.21 \\
\hline & 372 & $6.70 \mathrm{E}-03$ & 7.07E-03 & 1.20 \\
\hline & 373 & $6.60 \mathrm{E}-03$ & $6.96 \mathrm{E}-03$ & 1.19 \\
\hline & 374 & 6.47E-03 & $6.82 \mathrm{E}-03$ & 1.16 \\
\hline & 375 & $6.29 \mathrm{E}-03$ & $6.63 \mathrm{E}-03$ & 1.13 \\
\hline & 376 & $6.05 \mathrm{E}-03$ & $6.38 \mathrm{E}-03$ & 1.09 \\
\hline & 377 & $5.75 \mathrm{E}-03$ & $6.06 \mathrm{E}-03$ & 1.03 \\
\hline & 378 & $5.36 \mathrm{E}-03$ & $5.65 E-03$ & 0.96 \\
\hline & 379 & $4.91 \mathrm{E}-03$ & $5.18 \mathrm{E}-03$ & 0.88 \\
\hline & 380 & $5.22 \mathrm{E}-03$ & $5.50 \mathrm{E}-03$ & 0.94 \\
\hline \multirow{18}{*}{20} & 381 & $5.52 \mathrm{E}-03$ & $5.82 \mathrm{E}-03$ & 0.99 \\
\hline & 382 & $5.18 \mathrm{E}-03$ & $5.46 \mathrm{E}-03$ & 0.93 \\
\hline & 383 & $5.75 E-03$ & $6.06 \mathrm{E}-03$ & 1.03 \\
\hline & 384 & $6.15 \mathrm{E}-03$ & $6.48 \mathrm{E}-03$ & 1.11 \\
\hline & 385 & $6.48 \mathrm{E}-03$ & $6.83 \mathrm{E}-03$ & 1.16 \\
\hline & 386 & $6.72 \mathrm{E}-03$ & 7.09E-03 & 1.21 \\
\hline & 387 & $6.97 \mathrm{E}-03$ & $7.35 \mathrm{E}-03$ & 1.25 \\
\hline & 388 & $7.10 \mathrm{E}-03$ & $7.48 \mathrm{E}-03$ & 1.28 \\
\hline & 389 & $7.25 \mathrm{E}-03$ & $7.64 \mathrm{E}-03$ & 1.30 \\
\hline & 390 & $7.26 \mathrm{E}-03$ & $7.65 E-03$ & 1.30 \\
\hline & 391 & $7.29 \mathrm{E}-03$ & 7.69E-03 & 1.31 \\
\hline & 392 & $7.25 \mathrm{E}-03$ & 7.64E-03 & 1.30 \\
\hline & 393 & $7.16 \mathrm{E}-03$ & $7.54 \mathrm{E}-03$ & 1.29 \\
\hline & 394 & $7.02 \mathrm{E}-03$ & $7.40 \mathrm{E}-03$ & 1.26 \\
\hline & 395 & $6.82 \mathrm{E}-03$ & 7.19E-03 & 1.23 \\
\hline & 396 & 6.59E-03 & 6.94E-03 & 1.18 \\
\hline & 397 & $6.25 \mathrm{E}-03$ & $6.58 \mathrm{E}-03$ & 1.12 \\
\hline & 398 & $5.83 \mathrm{E}-03$ & $6.14 \mathrm{E}-03$ & 1.05 \\
\hline
\end{tabular}


ECAR-2705

Rev. 0
Physics Analysis to Support Advanced Test Reactor Critical

Facility Testing of the KJRR-FAI Experiment

\begin{tabular}{|c|c|c|c|c|}
\hline Plate & Node & $\begin{array}{c}\text { Total } \\
\text { MeV/source } \\
\text { particle }\end{array}$ & $\mathrm{MeV} / \mathrm{cc}$ & $\begin{array}{l}\text { Point To } \\
\text { Average }\end{array}$ \\
\hline & 399 & $5.28 \mathrm{E}-03$ & $5.56 \mathrm{E}-03$ & 0.95 \\
\hline & 400 & $5.46 \mathrm{E}-03$ & $5.76 \mathrm{E}-03$ & 0.98 \\
\hline \multirow{20}{*}{21} & 401 & $4.98 \mathrm{E}-03$ & $5.25 \mathrm{E}-03$ & 0.90 \\
\hline & 402 & $4.86 \mathrm{E}-03$ & $5.12 \mathrm{E}-03$ & 0.87 \\
\hline & 403 & $5.38 \mathrm{E}-03$ & $5.67 \mathrm{E}-03$ & 0.97 \\
\hline & 404 & $5.76 \mathrm{E}-03$ & $6.08 \mathrm{E}-03$ & 1.04 \\
\hline & 405 & $6.10 \mathrm{E}-03$ & $6.43 \mathrm{E}-03$ & 1.10 \\
\hline & 406 & $6.38 \mathrm{E}-03$ & $6.72 \mathrm{E}-03$ & 1.15 \\
\hline & 407 & $6.56 \mathrm{E}-03$ & $6.91 \mathrm{E}-03$ & 1.18 \\
\hline & 408 & $6.72 \mathrm{E}-03$ & $7.09 \mathrm{E}-03$ & 1.21 \\
\hline & 409 & $6.84 \mathrm{E}-03$ & $7.21 \mathrm{E}-03$ & 1.23 \\
\hline & 410 & $6.87 \mathrm{E}-03$ & $7.25 \mathrm{E}-03$ & 1.24 \\
\hline & 411 & $6.89 \mathrm{E}-03$ & $7.27 \mathrm{E}-03$ & 1.24 \\
\hline & 412 & $6.85 \mathrm{E}-03$ & $7.22 \mathrm{E}-03$ & 1.23 \\
\hline & 413 & $6.75 \mathrm{E}-03$ & $7.11 \mathrm{E}-03$ & 1.21 \\
\hline & 414 & $6.63 \mathrm{E}-03$ & $6.99 \mathrm{E}-03$ & 1.19 \\
\hline & 415 & $6.44 \mathrm{E}-03$ & $6.79 \mathrm{E}-03$ & 1.16 \\
\hline & 416 & $6.20 \mathrm{E}-03$ & $6.53 \mathrm{E}-03$ & 1.11 \\
\hline & 417 & $5.88 \mathrm{E}-03$ & $6.20 \mathrm{E}-03$ & 1.06 \\
\hline & 418 & $5.49 \mathrm{E}-03$ & $5.78 \mathrm{E}-03$ & 0.99 \\
\hline & 419 & $4.92 \mathrm{E}-03$ & $5.18 \mathrm{E}-03$ & 0.88 \\
\hline & 420 & 4.90E-03 & 5.17E-03 & 0.88 \\
\hline \multicolumn{4}{|c|}{ Max Peak to Average Power Density } & 1.31 \\
\hline
\end{tabular}




\section{Attachment B - Calculated reactivity changes for core reconfiguration}

The ATRC core will be modified from the configuration documented in Table B-1 to the configuration documented in Table 1. Replacement/removal of various test hardware and fuel elements will result in a change in reactivity that needs to be addressed to support the ATRC test plan. The calculated reactivity changes prior to insertion of KJRR-FAI are presented in Table B-2. 
Table B-1. ATRC Core Loading 12-13

\begin{tabular}{|c|c|}
\hline Facility & Loading \\
\hline \multicolumn{2}{|l|}{ Flux Traps } \\
\hline NW & LIPT and 3.5-inch diameter aluminum filler \\
\hline $\mathrm{E}$ & $\begin{array}{l}\text { Safety rod, Chopped Dummy IPT (CDIPT), and Small Irradiation Housing } \\
\text { Assembly (SIHA) with aluminum baskets containing aluminum fillers in positions } \\
\text { E-1 through E-6 and an aluminum basket containing three LSA cobalt capsules in } \\
\text { Position E-7. }\end{array}$ \\
\hline S & $\begin{array}{l}\text { Safety rod, Chopped Dummy IPT (CDIPT), and the SPICE Irradiation Facility with } \\
\text { the SPICE-9 Capsule Basket Assembly }\end{array}$ \\
\hline NE & ATRC AGR 3/4 Assembly with Test Train and Neutron Filter \\
\hline $\mathrm{N}$ & $\begin{array}{l}\text { Safety rod, Standard Inpile Tube (SIPT), flow tube, and 1.5-inch diameter } \\
\text { aluminum filler }\end{array}$ \\
\hline W & $\begin{array}{l}\text { Safety rod, Standard Inpile Tube (SIPT), flow tube, and 1.5-inch diameter } \\
\text { aluminum filler }\end{array}$ \\
\hline SW & $\begin{array}{l}\text { Safety rod, Standard Inpile Tube (SIPT), flow tube, and 1.5-inch diameter } \\
\text { aluminum filler }\end{array}$ \\
\hline C & Center IPT consisting of pressure tube and water-filled flow tube \\
\hline SE & $\begin{array}{l}\text { Dummy Flux Trap Filler, Standard Inpile Tube (SIPT), flow tube, and 1.5-inch } \\
\text { diameter aluminum filler }\end{array}$ \\
\hline \multicolumn{2}{|l|}{ A Irradiation Facilities } \\
\hline A-1 through A-8 & Aluminum filler \\
\hline A-10 & Outboard 'A' MT FMWH \\
\hline $\mathrm{A}-9, \mathrm{~A}-11$, and $\mathrm{A}-12$ & Aluminum filler \\
\hline \multicolumn{2}{|l|}{ B Irradiation Facilities } \\
\hline B-1 through B-8 & "Y" aluminum flow restrictor \\
\hline \multicolumn{2}{|l|}{ H Irradiation Facilities } \\
\hline $\begin{array}{l}\mathrm{H}-2, \mathrm{H}-6, \mathrm{H}-10 \text {, and } \mathrm{H}- \\
14\end{array}$ & Empty flux monitor wire holders \\
\hline $\mathrm{H}-3$ and $\mathrm{H}-11$ & $\mathrm{~N}-16$ flow tube mockup \\
\hline $\begin{array}{l}\mathrm{H}-1, \mathrm{H}-4, \mathrm{H}-5, \mathrm{H}-7, \mathrm{H}-8 \\
\mathrm{H}-9, \mathrm{H}-12, \mathrm{H}-13, \mathrm{H}-15 \\
\text { and } \mathrm{H}-16\end{array}$ & Aluminum basket containing three LSA cobalt capsules \\
\hline \multicolumn{2}{|l|}{ I Irradiation Facilities } \\
\hline I-1 through I-20 & $\begin{array}{l}\text { Aluminum filler except for Positions I-3 and I-9 which contain log count rate } \\
\text { detector thimbles }\end{array}$ \\
\hline Fuel Elements & Forty ATRC standard fuel elements \\
\hline Neck Shims & All inserted \\
\hline NW, NE, SW, SE N-16 & Aluminum $\mathrm{N}-16$ flow tube mockup \\
\hline
\end{tabular}


ECAR-2705

Rev. 0

Facility Testing of the KJRR-FAI Experiment

Table B-2. Calculated Reactivity Changes Prior to KJRR-FAl Insertion

\begin{tabular}{|c|c|c|c|c|c|}
\hline Step & Facility & Initial Loading & New Loading & keff & Reactivity Change \\
\hline 0 & -- & Table B-2 & - & 0.99407 & 0 \\
\hline 1 & NW & $\begin{array}{l}\text { LIPT and 3.5-inch } \\
\text { diameter aluminum filler }\end{array}$ & $\begin{array}{l}\text { NR Dual Holder with } \\
100 \% \text { Hf shrouds and } \\
\text { Zr holders }\end{array}$ & 0.99037 & -0.52 \\
\hline 2 & E & $\begin{array}{l}\text { Safety rod, Chopped } \\
\text { Dummy IPT (CDIPT), and } \\
\text { Small Irradiation Housing } \\
\text { Assembly (SIHA) with } \\
\text { aluminum baskets } \\
\text { containing aluminum } \\
\text { fillers in Positions E-1 } \\
\text { through E- } 6 \text { and an } \\
\text { aluminum basket } \\
\text { containing three LSA } \\
\text { cobalt capsules in } \\
\text { Position E-7. }\end{array}$ & $\begin{array}{l}\text { Safety rod, Chopped } \\
\text { Dummy IPT (CDIPT), } \\
\text { and Small Irradiation } \\
\text { Housing Assembly } \\
\text { (SIHA) with } \\
\text { aluminum baskets } \\
\text { containing three LSA } \\
\text { cobalt capsules in } \\
\text { Positions E-1, E-2, } \\
\text { E-3, E-4, E-5, E-6, and } \\
\text { E-7. }\end{array}$ & 0.98523 & -0.73 \\
\hline 3 & $\mathrm{~s}$ & $\begin{array}{l}\text { Safety rod, Chopped } \\
\text { Dummy IPT (CDIPT), and } \\
\text { the SPICE Irradiation } \\
\text { Facility with the SPICE-9 } \\
\text { Capsule Basket Assembly }\end{array}$ & $\begin{array}{l}\text { Safety rod, Chopped } \\
\text { Dummy IPT (CDIPT), } \\
\text { and the SPICE } \\
\text { Irradiation Facility } \\
\text { with the MICE Al } \\
\text { secondary filler }\end{array}$ & 0.98925 & 0.57 \\
\hline 4 & $\mathrm{NE}$ & $\begin{array}{l}\text { ATRC AGR } 3 / 4 \text { Assembly } \\
\text { with Test Train and } \\
\text { Neutron Filter }\end{array}$ & $\begin{array}{l}\text { Water filled flux trap } \\
\text { baffle }\end{array}$ & 0.99168 & 0.34 \\
\hline 5 & $\mathrm{~N}$ & $\begin{array}{l}\text { Safety rod, Standard } \\
\text { Inpile Tube (SIPT), flow } \\
\text { tube, and } 1.5 \text {-inch } \\
\text { diameter aluminum filler }\end{array}$ & $\begin{array}{l}\text { Safety rod, Standard } \\
\text { Inpile Tube (SIPT), } \\
\text { water-filled flow } \\
\text { tube }\end{array}$ & 0.98988 & -0.25 \\
\hline 6 & SE & $\begin{array}{l}\text { Dummy Flux Trap Filler, } \\
\text { Standard Inpile Tube } \\
\text { (SIPT), flow tube, and } \\
\text { 1.5-inch diameter } \\
\text { aluminum filler }\end{array}$ & $\begin{array}{l}\text { Dummy Flux Trap } \\
\text { Filler, Standard Inpile } \\
\text { Tube (SIPT), water- } \\
\text { filled flow tube }\end{array}$ & 0.98706 & -0.40 \\
\hline 7 & $\begin{array}{l}\text { A-1 through } \\
\text { A-8 }\end{array}$ & Aluminum filler & $\begin{array}{l}\text { Aluminum basket } \\
\text { containing three LSA } \\
\text { cobalt capsules }\end{array}$ & 0.98104 & -0.86 \\
\hline \multirow{2}{*}{8} & $A-10$ & $\begin{array}{l}\text { Outboard 'A' MT } \\
\text { FMWH* }\end{array}$ & \multirow{2}{*}{$\begin{array}{l}\text { Aluminum basket } \\
\text { containing three LSA } \\
\text { cobalt capsules }\end{array}$} & \multirow{2}{*}{0.97782} & \multirow{2}{*}{-0.47} \\
\hline & $\begin{array}{l}\text { A-9, A-11, } \\
\text { and A-12 }\end{array}$ & Aluminum filler & & & \\
\hline
\end{tabular}


ECAR-2705

Rev. 0

Table B-2. Calculated Reactivity Changes (continued)

\begin{tabular}{|c|c|c|c|c|c|}
\hline Step & Facility & Initial Loading & New Loading & keff & Reactivity Change \\
\hline 9 & $\begin{array}{l}\text { B-1 through } \\
\text { B-8 }\end{array}$ & $\begin{array}{l}\text { "Y" aluminum flow } \\
\text { restrictor }\end{array}$ & $\begin{array}{l}\text { Y-basket containing } \\
\text { aluminum basket } \\
\text { containing three LSA } \\
\text { cobalt capsules }\end{array}$ & 0.97122 & -0.97 \\
\hline \multirow{6}{*}{10} & $\mathrm{H}-2$ and $\mathrm{H}-10$ & $\begin{array}{l}\text { Empty flux monitor wire } \\
\text { holders }\end{array}$ & $\begin{array}{l}\text { Empty flux monitor } \\
\text { wire holders }\end{array}$ & \multirow{6}{*}{0.96609} & \multirow{6}{*}{-0.76} \\
\hline & $\mathrm{H}-6$ & $\begin{array}{l}\text { Empty flux monitor wire } \\
\text { holder }\end{array}$ & $\begin{array}{l}\text { Aluminum basket } \\
\text { containing three LSA } \\
\text { cobalt capsules }\end{array}$ & & \\
\hline & $\mathrm{H}-14$ & $\begin{array}{l}\text { Empty flux monitor wire } \\
\text { holder }\end{array}$ & Hf neck shim & & \\
\hline & $\mathrm{H}-3$ and $\mathrm{H}-11$ & $\mathrm{~N}-16$ flow tube mockup & $\begin{array}{l}\mathrm{N}-16 \text { flow tube } \\
\text { mockup }\end{array}$ & & \\
\hline & $\begin{array}{l}\mathrm{H}-5, \mathrm{H}-8, \mathrm{H}- \\
13, \mathrm{H}-15 \text {, and } \\
\mathrm{H}-16\end{array}$ & $\begin{array}{l}\text { Aluminum basket } \\
\text { containing three LSA } \\
\text { cobalt capsules }\end{array}$ & $\begin{array}{l}\text { Aluminum basket } \\
\text { containing three LSA } \\
\text { cobalt capsules }\end{array}$ & & \\
\hline & $\begin{array}{l}\mathrm{H}-1, \mathrm{H}-4, \mathrm{H}-7, \\
\mathrm{H}-9 \text {, and } \mathrm{H}- \\
12\end{array}$ & $\begin{array}{l}\text { Aluminum basket } \\
\text { containing three LSA } \\
\text { cobalt capsules }\end{array}$ & Hf neck shims & & \\
\hline \multicolumn{6}{|c|}{ Fuel Elements } \\
\hline 11 & Element 5 & Mark V Element & Mark VII Element & 0.9662 & 0.02 \\
\hline 12 & Element 22 & Mark V Element & Mark VII NB Element & 0.97017 & 0.59 \\
\hline 13 & Element 23 & Mark V Element & Mark VII NB Element & 0.97434 & 0.61 \\
\hline 14 & Element 24 & Mark V Element & Mark VII NB Element & 0.97836 & 0.59 \\
\hline 15 & Element 25 & Mark V Element & Mark VII NB Element & 0.98223 & 0.56 \\
\hline 16 & Element 26 & Mark V Element & Mark VII NB Element & 0.9858 & 0.51 \\
\hline 17 & Element 27 & Mark V Element & Mark VII NB Element & 0.98968 & 0.55 \\
\hline 18 & Element 28 & Mark V Element & Mark VII NB Element & 0.99463 & 0.70 \\
\hline 19 & Element 29 & Mark V Element & Mark VII NB Element & 0.99987 & 0.73 \\
\hline \multicolumn{5}{|c|}{ Total Change in reactivity } & 0.81 \\
\hline \multicolumn{6}{|c|}{ fillers were modeled in place of FMWH. The difference in reactivity will be sma } \\
\hline
\end{tabular}

